\title{
The role of proopiomelanocortin (POMC) neurones in feeding behaviour
}

\author{
George WM Millington
}

Address: Division of Medicine, Norfolk and Norwich University Hospital, Colney Lane, Norwich, NR4 7UZ, UK

Email: George WM Millington - gwm_millington@yahoo.co.uk

Published: I September 2007

Nutrition \& Metabolism 2007, 4:18 doi:10.1 I86/I743-7075-4-18
Received: 5 May 2007

Accepted: I September 2007

This article is available from: http://www.nutritionandmetabolism.com/content/4/I/I8

(C) 2007 Millington; licensee BioMed Central Ltd.

This is an Open Access article distributed under the terms of the Creative Commons Attribution License (http://creativecommons.org/licenses/by/2.0), which permits unrestricted use, distribution, and reproduction in any medium, provided the original work is properly cited.

\begin{abstract}
The precursor protein, proopiomelanocortin (POMC), produces many biologically active peptides via a series of enzymatic steps in a tissue-specific manner, yielding the melanocyte-stimulating hormones (MSHs), corticotrophin (ACTH) and $\beta$-endorphin. The MSHs and ACTH bind to the extracellular G-protein coupled melanocortin receptors (MCRs) of which there are five subtypes. The MC3R and MC4R show widespread expression in the central nervous system (CNS), whilst there is low level expression of MCIR and MC5R. In the CNS, cell bodies for POMC are mainly located in the arcuate nucleus of the hypothalamus and the nucleus tractus solitarius of the brainstem. Both of these areas have well defined functions relating to appetite and food intake. Mouse knockouts (ko) for pomc, $m c 4 r$ and $m c 3 r$ all show an obese phenotype, as do humans expressing mutations of POMC and MC4R. Recently, human subjects with specific mutations in $\beta$ $M S H$ have been found to be obese too, as have mice with engineered $\beta$-endorphin deficiency. The CNS POMC system has other functions, including regulation of sexual behaviour, lactation, the reproductive cycle and possibly central cardiovascular control. However, this review will focus on feeding behaviour and link it in with the neuroanatomy of the POMC neurones in the hypothalamus and brainstem.
\end{abstract}

\section{Background}

Over the last decade, there has been much research on the role of hypothalamic POMC neurones, with regard to appetite. However, POMC products (the MSHs, ACTH and $\beta$-endorphin) also have important roles in the skin, stress response, immune system and sexual function [1-6]. Experimental evidence suggests that POMC neurones form an integral part of the central melanocortin system regulating feeding behaviour. One or more of the melanocortins and $\beta$-endorphin, released from these POMC neurones, may be involved in this regulation. When specific genes in the CNS melanocortin system (POMC, PC1, $M C 4 R$ and $M C 3 R$ ) are found mutated in either humans or rodents, this results in an obese phenotype [7-9].
There have been two recent excellent reviews regarding the electrophysiology of feeding circuits and the neuroanatomy of POMC $[10,11]$. However, the focus of this review is the function of POMC projections in the CNS, which originate from the arcuate nucleus of the hypothalamus and the brainstem and their role in appetite and feeding control. The review begins with a brief overview of feeding systems and specifically the role of leptin as a major peripheral signal to the POMC arcuate neurones. Then, the basic biology of POMC and melanocortin receptors is discussed, together with some observations from human genetic studies. The next section deals with the two groups of POMC neurones in the arcuate nucleus and brainstem, as well as their melanocortin and $\beta$-endorphin products, 
MC4R, MC3R and feeding. This is set in the context of other neurotransmitter systems that have been shown to interact with the melanocortin system in these two brain regions. Then other brain regions that might be targets for POMC mediated effects are discussed, namely the paraventricular nucleus (PVN), lateral hypothalamus, dorsomedial nucleus (DMH), supraoptic nucleus (SON), ventromedial nucleus (VMH), periventricular nucleus, nucleus accumbens and amygdala. As far as possible, other interacting neurotransmitters are discussed in the sections relating to where their cell bodies or projections are located.

\section{Feeding and energy homeostasis}

Feeding is primarily a response to habitually entrained rhythms, including circadian rhythms. Feeding behaviour is regulated by a system with the hypothalamus at the centre, where how much we eat is a response to an internal energy status [12]. There are complex but integrated interconnections between the hypothalamic nuclei that maintain energy homeostasis through regulation of food intake and energy expenditure [13-16]. One of the key components of the hypothalamic system is the POMC neurones of the arcuate nucleus $[10,11]$. One of the main longer term peripheral signals is the hormone leptin $[10,11]$.

\section{Leptin and hypothalamic regulation}

The site of leptin's action is the mediobasal hypothalamus, principally the hypothalamic arcuate nucleus, via the long form of the leptin receptor (LEPRB) that influences the activities of two separate groups of neurones with opposing feeding functions. These include POMC neurones that co-express CART and AgRP neurones that co-express NPY. These arcuate POMC neurones have processes close to the fenestrated capillaries of the median eminence and can thus be targeted by hormones such as leptin in the circulation [17]. POMC neurones in the arcuate nucleus, which express LEPRB, are activated by leptin. They project to the DMH, PVN and lateral hypothalamus $[10,11]$. Leptin may thus be the signal linking peripheral energy stores with POMC signalling activity in the hypothalamus. LEPRB is also expressed in many other hypothalamic nuclei that may have a role in appetite. These include the $\mathrm{DMH}, \mathrm{VMH}, \mathrm{PVN}$, lateral hypothalamic area, periventricular nucleus and SON $[18,19]$. It must be remembered that not all mammalian hypothalamic POMC neurones express leptin receptors $[20,21]$, suggesting the existence of a leptin-unrelated melanocortin signalling system too.

\section{Proopiomelanocortin (POMC) genetics and its post-translational modification}

POMC is the precursor of the MSHs and adrenocorticotrophin (ACTH), as well as $\beta$-endorphin (Figure 1). The MSHs and ACTH are collectively known as melanocortins.
All sequenced mammalian $P O M C$ genes consist of three exons, interspersed by large introns (Figure $1 ;[22,23]$ ). pomc mRNA is synthesised in the pituitary, the arcuate nucleus, the nucleus tractus solitarius of the brainstem (NTS) and several peripheral tissues. This mRNA forms a single protein, which passes to the Golgi bodies. The signal peptide sequence directs it into secretory granules where post-translational processing yields many peptides by successive, cell-specific, enzymatic modifications (Figure $1 ;[24-27])$. Cleavage by the propeptide convertases PC1 and PC2 occurs at specific pairs of basic residues, Lys and Arg [28-30]. PC1 alone is expressed in the pituitary corticotrophs and cleaves POMC, producing the $\mathrm{NH}_{2}$-terminal peptide (NT), joining peptide (JP), ACTH, $\beta$-lipotrophin $(\beta-\mathrm{LPH})$ and $\beta$-endorphin. Melanotrophs generate PC1, PC2, carboxypeptidase E (CPE)), amidating and $N$-acetylating enzymes to produce $\alpha-\mathrm{MSH}$ and $\beta$ endorphin $[28,29,31,32]$. PC2 cleaves the first 14 amino acidsof ACTH to generate ACTH (1-14) OH. PC2 cleaves $\beta$-LPH to produce $\beta$-MSH and $\beta$-endorphin. The ACTH (1-14) $\mathrm{OH}$, after COOH-terminal amidation, produces desacetyl- $\alpha-\mathrm{MSH}$, a step required for biologic activity. $\alpha-$ $\mathrm{N}$-acetylation of the NT enhances the action of $\alpha-\mathrm{MSH}$ and inhibits the action of $\beta$-endorphin [33]. O-acetylation of $\alpha$-MSH forms $N, O$-diacetyl- $\alpha-\mathrm{MSH}$. PC2 ko mice produce no $\alpha-\mathrm{MSH}$ at all [34]. PC1 or PC2 may produce the $\gamma$-MSHs but the mechanism is not clear $[28,29]$. Paired amino-acid converting enzyme 4 (PACE4) colocalises with POMC in the hypothalamus [35]. Both PACE4 and POMC converting enzyme (PCE), a secretory vesicle aspartyl protease, can cleave POMC in vitro $[35,36]$. How these additional enzymes interact with PC1 and PC2 is not clear at present. The subject of POMC processing in the hypothalamus has been reviewed in more detail recently [37].

\section{The genetic pathology of the mammalian melanocortin system}

POMC deficiency in mice and humans and PC1 homozygous mutations in humans are characterised by adrenal failure, early-onset obesity and, with POMC mutations, altered pigmentation and tall stature $[7,9,38]$. Similarly, cpe ko mice show obesity, as well as a number of other endocrine defects [27]. Subjects with the human genetic obesity disorder, Prader-Willi syndrome, have reduced levels of PC2 in their hypothalami on immunocytochemical assessment [39].

A point mutation in the cleavage site between $\beta$-MSH and $\beta$-endorphin (Figure 1) forms an aberrant fusion protein, which causes obesity in humans, perhaps by altering central melanocortin signalling in the CNS [40]. Heterozygous mutations in MC4R also cause obesity and tall stature in humans [7]. Recent data suggests that $\beta-\mathrm{MSH}$ may be the important POMC product in inhibiting feed- 


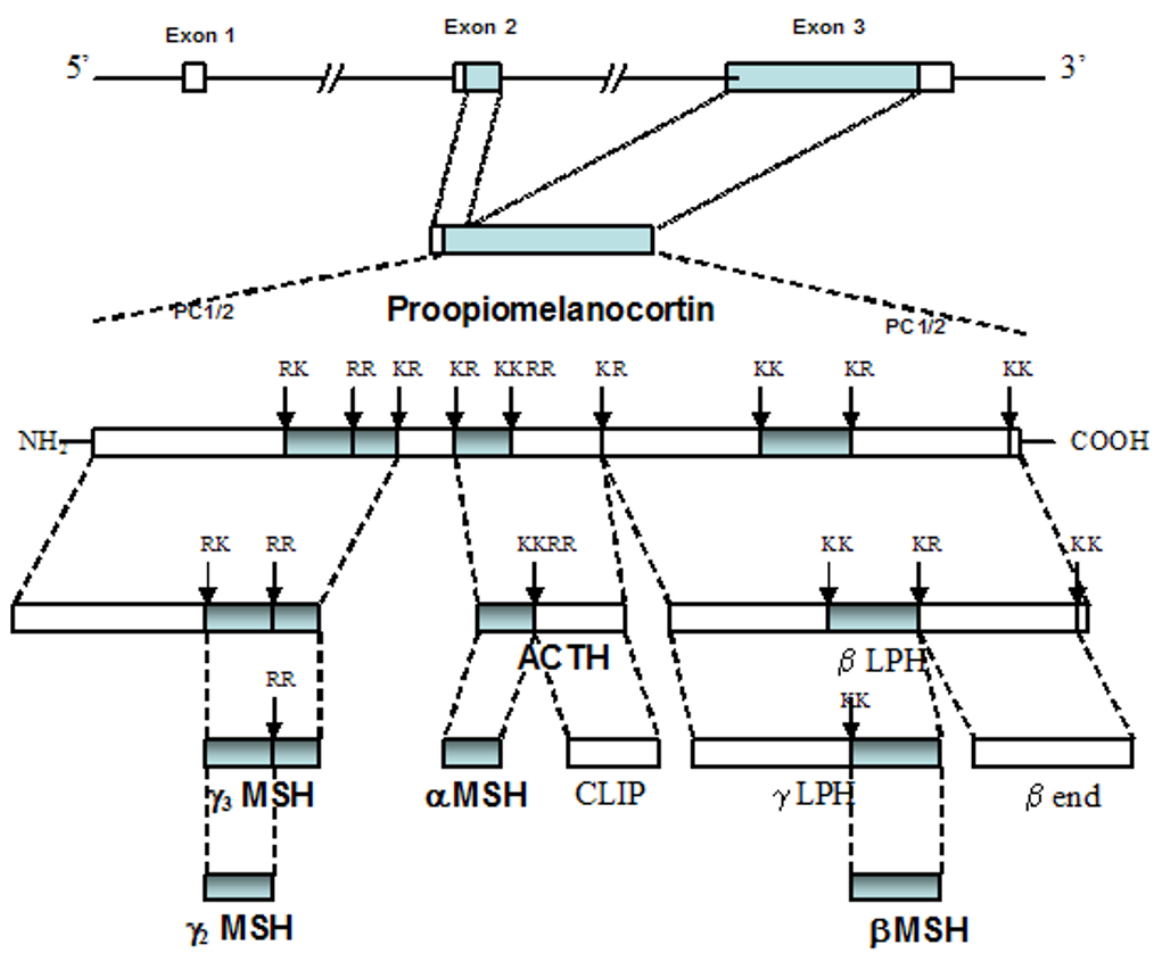

Figure I

Gene structure and post-translational processing of proopiomelanocortin (POMC). POMC in mammals consists of 3 exons, of which exons 2 and 3 are translated. Prohormone convertases I and 2 (PCI/2) break the parent POMC peptide into successively smaller peptides by cleavage at paired dibasic amino acid residues consisting of lysine (K) and/or arginine (R). The final products are generated in a tissue specific manner, for example $\alpha-M S H$ and ACTH are not produced by the same cells in the pituitary. They also involve additional enzymatic post translational modifications, such as the acetylation of $\alpha-M S H$. The final products include the melanocortins (MSHs and ACTH), $\beta$-endorphin ( $\beta$-end) and corticotrophin-like intermediate peptide (CLIP). There are intermediate peptides whose biological function remains unclear, such as $\beta$ and $\gamma$ lipotrophins $(\beta$-LPH, $\gamma$ LPH).

ing centrally in humans [41], but not rodents, as rodents do not produce $\beta-\mathrm{MSH}$ physiologically $[7,42]$.

Mendelian human POMC disorders are very rare [43], but there is linkage between POMC and other obesity related traits, suggesting that it may form part of a common genetic obesity predisposition $[44,45]$. These findings suggest a clinically relevant role for POMC within the feeding circuits in the CNS.

\section{Melanocortin receptors (MCRs)}

The melanocortins all contain the amino acid sequence His-Phe-Arg-Trp, required for receptor occupancy. The MCRs are part of the G-protein coupled receptor family. Five MCRs are cloned, the MC1R, MC2R, MC3R, MC4R and MC5R [46]. MC1R is predominantly the $\alpha-M S H$ receptor and $M C 2 R$ the $A C T H$ receptor. In radioligand binding studies, $\beta$-MSH shows more affinity to the MC4R than $\alpha-\mathrm{MSH}$, with $\gamma$-MSH having the least affinity. $\gamma$-MSH binds to the MC3R more than $\alpha$ - or $\beta$-MSH. MCR signalling activates adenyl cyclase, leading to accumulation of CAMP, as well as protein kinase $\mathrm{C}$ (PKC) and diacylglycerol (DAG) downstream $[1,46]$.

\section{POMC neurones and the arcuate nucleus}

The arcuate nucleus lies at the base of the hypothalamus. It is responsive to peripheral stimuli such as leptin. Leptin is essential in the neonatal phase for the development of neuronal projections from the arcuate nucleus to the DMH, PVN and lateral hypothalamus in succession, as shown by DiI (1,1'-dioctadecyl-3,3,3',3'-tetramethylindocarbocyanine perchlorate) axonal labelling [47].

\section{POMCICART and NPYIAgRP neuronal pathways from the arcuate nucleus}

There are two main neuronal populations located in the arcuate nucleus regulating appetite. There is evidence from both gene and protein expression studies that the 
Table I: A summary of the experimental evidence for the presence of POMC axonal projections involved in feeding behaviour (axonal labelling vs immunocytochemistry references indicated numerically)

\begin{tabular}{lll}
\hline $\begin{array}{l}\text { Arcuate POMC } \\
\text { projections: }\end{array}$ & $\begin{array}{l}\text { Axonal } \\
\text { labelling }\end{array}$ & Immunocytochemistry \\
\hline $\begin{array}{ll}\text { Arcuate nucleus } \\
\text { Brainstem }\end{array}$ & 57 & $48,62,93,119$ \\
PVN & 91 & 91 \\
Lateral hypothalamus & - & 62,93 \\
DMH & 160 & 93 \\
SON & - & 93 \\
VMH & - & 93 \\
Periventricular nucleus & - & 93 \\
Nucleus accumbens & - & 93 \\
Amygdala & - & 93 \\
\hline
\end{tabular}

satiety neurones produce both POMC and cocaine and amphetamine regulated transcript (CART) [48]. Food restriction reduces hypothalamic pomc mRNA expression [49], whereas hypothalamic pomc mRNA expression is increased in overfed rats [50]. The orexigenic neurones contain NPY and agouti-related peptide (AgRP). Fasting activates mRNA expression in hypothalamic NPY neurones [51]. NPY is thought to be one of the strongest stimuli to feeding [51] perhaps partly acting by inhibiting arcuate nucleus pomc mRNA expression via the $\mathrm{Y}_{2}$ receptor [52]. The major function of AgRP is to stimulate feeding by antagonising melanocortins at the MC3R and MC4R in the hypothalamus [53]. Selective ablation of NPY/AgRPexpressing neurones in adult mice results in acute reduction of feeding [54]. AgRP polymorphisms are associated with inherited leanness in humans [55]. In the parvocellular division of the paraventricular nucleus, close apposition of the perikarya of POMC/CART neurones and NPY/ AgRP-containing terminals is seen. CART arcuate nucleus neurones markedly inhibit NPY-induced feeding in fasted and normal rats [56].

Both the POMC/CART and NPY/AgRP pathways express LEPRB and project to the leptin-dependent regions in the $\mathrm{DMH}, \mathrm{PVN}$ and lateral hypothalamus (Table 1). Leptin has opposite effects on each pathway with regard to feeding, facilitating transmission in the POMC/CART system and inhibiting the NPY/AgRP neurones, when measure by a system using fluorescent protein (GFP)-tagged POMC (red) and NPY (green) neurones [57]. Surgical disruption of the arcuate nucleus to PVN connection in rats results in increased food intake and weight gain, including body fat, implying that the balance of the background anorexigenic effects of POMC/CART neurones is greater than the orexigenic effects of the NPY/AgRP neurones [58]. It must be born in mind that lesioning experiments are likely to dis- rupt many neuronal connections and their interpretation requires some caution.

Using $o b / o b$ mice expressing GFP on both POMC and NPY neurones in the arcuate nucleus, leptin-deficiency has been shown to increase both the number of excitatory synapses to NPY/AgRP neurones and the number of inhibitory synapses to POMC/CART neurones. When leptin is given to the $o b / o b$ mice, synaptic numbers revert to the wild type pattern within 6 hours [57]. Fasting leads to an increase in the action potential of the arcuate nucleus NPY/AgRP neurones in normal mice, but this is not seen in $o b / o b$ or $d b / d b$ strains lacking central leptin signalling [59]. This leptin-induced neuronal plasticity may relate to its role as a signal of fat stores. Melanotan II (MTII), an MC3R/MC4R agonist reduces the orexigenic and adipogenic effects of NPY, but does not alter NPY-induced suppression of the reproductive and growth neuroendocrine axes [60]. A large proportion of NPY neurones in the rat hypothalamus express $m c 3 r$ mRNA while a much lower number of NPY neurones express $m c 4 r$ mRNA, suggesting that POMC neurones may directly modulate the activity of the hypothalamic NPY system too, mainly through activation of MC3R [61].

A subpopulation of arcuate nucleus NPY/AgRP/GABAproducing neurones, identified immunocytochemically, project to the PVN and send inhibitory GABA collaterals to arcuate nucleus POMC neurones that express GFP [62]. GABA blocks the anorexic effect of icv $\alpha-M S H$, whereas a GABA antagonist increases the anorexia [63]. Thus, GABA facilitates the feeding effect of NPY at target sites in the PVN, by blocking opposing POMC transmission. However, in $o b / o b$ mice (who congenitally lack leptin, leading to obesity), leptin deficiency exaggerates the direct inhibitory effect of NPY neurones on POMC neurones in the arcuate nucleus, an effect independent of the actions of GABA [64]. Also, approximately one-third of POMC/ CART neurones express glutamic acid decarboxylase (GAD) mRNA [47]. GAD is the enzyme necessary to produce GABA, although GABA is not thought to inhibit the $\mathrm{NPY} / \mathrm{AgRP}$ neurones and its exact function is unknown at present. It may be involved more in the extra-hypothalamic projections of POMC [65]. There is recent immunocytochemical evidence that hypothalamic POMC neurones express cholinergic fibres too [66]. Studies utilising immuno-electron microscopy, immunocytochemistry and in-situ hybridisation show that both the NPY/ AgRP nerve fibres and the CART/POMC neurones are innervated by glutaminergic fibres too $[67,68]$. This links the control of feeding into wider feedback systems, for example glutamate neurones connect to the VMH, DMH and lateral hypothalamus, the other main feeding areas in the hypothalamus $[67,68]$. 


\section{AgRP - more than an antagonist of MC4R and MC3R?}

The melanocortins have two endogenous antagonists, agouti and AgRP, that show some subtype selectivity as MCR antagonists. AgRP only acts on the CNS receptors, MC4R and MC3R (Table 2; [69]). Both AgRP and the MSHs can bind to MC3R and MC4R either presynaptically or postsynaptically $[10,11]$. Like POMC, AgRP may undergo post-translational processing [70]. Both agouti and AgRP function as inverse agonists in vitro, so they may regulate their respective MCRs in vivo, even in the absence of melanocortins [71].

In hamsters, central administration of AgRP increases food hoarding more than food intake [72]. Does this suggest species differences in the response to AgRP, or perhaps actions other than pure antagonism of the melanocortin anorexic signal? $\mathrm{AgRP}_{83-132}$ has been shown to have effects in the $m c 4 r$ ko mouse, which could be attributable to $\mathrm{MC3R}$ antagonism, or perhaps as yet unknown effects on a different receptor system [73].

Perhaps AgRP neuronal activity is more directly linked to metabolic change than POMC neuronal activity? In the $o b / o b$ mouse, agrp gene expression is increased 5-10 fold compared with wild type $[74,75]$, whereas the absence of leptin only reduces pomc gene expression by approximately two-fold [76]. Others have found that there is virtually no change in hypothalamic pomc expression in either food restricted, fasted or leptin resistant (Zucker) rats versus controls [70]. Overall this gives a picture of a rather tonic anorexic signal from the POMC/CART neurones, perhaps with a more finely tuned and responsive orexigenic signal from the AgRP/NPY system? AgRP, its interactions with the melanocortin system and other roles has been well reviewed recently [70].

\section{Peptide YY and POMC}

Peptide YY (PYY) and NPY are part of the same peptide family, acting via the Y-group of receptors. After a meal, the gut releases PYY ${ }_{3-36}$ into the circulation, which crosses the BBB and reduces food intake by suppressing NPY release and increasing $P O M C$ release in the arcuate nucleus [77-80]. $\mathrm{PYY}_{3-36}$ inhibits the action potential firing activity of arcuate POMC neurones, acting through postsynaptic Y2 receptors [81]. However, mc4r ko, pomc ko and normal mice have similar anorexia with PYY, suggesting it can act independently of melanocortins too $[9,82]$. This may seem paradoxical, but could relate to differing development of the hypothalamic NPY/PYY system in the absence of pomc or $m c 4 r$ from birth.

\section{VGF, lethal yellow and POMC}

VGF (non-acronymic) is a hypothalamic neuropeptide coexpressed in POMC and NPY neurones, identified by immunocytochemistry, in the arcuate nucleus [83]. Lethal
Table 2: Melanocortin receptors and their endogenous antagonists

\begin{tabular}{cc}
\hline $\begin{array}{c}\text { Melanocortin } \\
\text { receptor }\end{array}$ & Endogenous antagonist \\
$M C I R$ & Agouti \\
$M C 2 R$ & Agouti \\
$M C 3 R$ & Agouti, AgRP \\
$M C 4 R$ & Agouti, AgRP \\
$M C 5 R$ & $?$ \\
\hline
\end{tabular}

yellow is an inbred obese mouse strain, resulting from overexpression of agouti, which then has excess AgRP-like actions in the CNS [69]. vgf ko mice are lean with normal food intake and increased oxygen consumption and locomotor activity at rest [83]. Crossing the vgf ko mouse with $o b / o b$ and lethal yellow mutants, improves the obesity of the $o b / o b$ mouse and prevents the lethal yellow obese phenotype. This suggests that the actions of VGF are downstream of AgRP and the melanocortins [83]. Arcuate nucleus $v g f$ mRNA expression is increased in hamsters in experimental short photoperiod situations mimicking winter, suggesting a feeding-related hibernation function for VGF [84].

\section{Galanin and POMC}

Cells in the arcuate nucleus, DMH and PVN show galanin immunocytochemical staining [85]. When injected icv, or directly into the PVN, VMH and lateral hypothalamus, galanin is mildly orexigenic, perhaps by facilitating NPY's actions $[85,86]$. Galanin blocks arcuate neuronal firing in those neurones expressing gal-r1 receptor mRNA, perhaps via direct contact with arcuate nucleus POMC neurones [87].

\section{POMC neurones and the brainstem}

POMC neurones in the NTS, expressing GFP, are activated both by cholecystokinin (CCK) and by satiety induced by feeding, as shown by immunocytochemical measurement of Fos protein [88]. The MC3R/MC4R antagonist SHU9119 administered icv prevents CCK-induced suppression of feeding, whether administered into the third or fourth ventricle [88]. This effect of CCK activating POMC "GFP" NTS neurones is blocked by a CCK antagonist and also antagonised by endogenous opioids [89]. The dorsal motor nucleus of the vagus nerve (DMX), lying next to the NTS, has the highest density of MC4R in the brain [90] and may mediate the anorexia due to activation of the NTS POMC neurones by CCK [88]. The DMX also receives fibres from the arcuate nucleus POMC neurones, as shown by immunocytochemistry (Table 1; [91]). Vagotomy results in a slight reduction in food intake, but no change in body weight. This is associated with activation on neurones in the NTS, as well as increased AgRP and decreased POMC mRNA expression in the hypothala- 
mus [92]. Using immunocytochemistry to demonstrate both POMC and AgRP fibres and in situ hybridisation to show their MC4R and MC3R targets (Table 3), much of the neuroanatomy of the melanocortin system has been mapped [93]. Interestingly, there are no AgRP neurones projecting to the POMC neurones in the brainstem [93]. The role of POMC neurones in the NTS and vagal afferents to both sets of POMC cell bodies requires further study.

\section{Leptin, POMC and the brainstem}

LEPRB is found in several brainstem nuclei involved in the control of food intake, such as the DMX, area postrema, NTS, parabrachial, hypoglossal, trigeminal, lateral reticular and cochlear nuclei, locus coeruleus and inferior olive [94]. Leptin injected into either the fourth or lateral ventricles, or into the dorsal vagal complex (DMX, AP and NTS), suppresses feeding [94]. This suggests that the brainstem neurones are just as effective at mediating anorexia as the hypothalamic neurones and, like POMC, are direct targets for the action of leptin in the control of energy homeostasis [94]. However, part of this effect may be being mediated by hypothalamic arcuate nucleus POMC cells, as retrograde tracing experiments showed that a small percentage of these hypothalamic neurones project to the dorsal vagal complex [91].

Also, when leptin is administered centrally it activates the arcuate POMC neurones, but not the NTS neurones [95]. Recently, leptin has been shown to modulate taste sensation directly, via the taste receptors, as well as via the brainstem [96]. Leptin could have a refining influence on feeding, via its actions on taste receptors and brainstem nuclei, but this is unlikely to involve brainstem POMC neurones in the process.

\section{MC4R and MC3R; feeding and obesity MC4R, feeding and obesity}

In contrast to the restricted distribution of the POMC neurones, MC4R and MC3R are widely present throughout the brain, although with different patterns of distribution
(Table 3). The evidence, either genetic or neuropharmacological, for the key role of MC4R in feeding and the pathogenesis of obesity is as follows.

The most common monogenic forms of human obesity are MC4R mutations [7]. Murine and human $M C 4 R$ homozygous mutants are obese and hyperphagic [97100]. Murine and human MC4R heterozygous mutants are obese to a lesser extent. This shows sensitivity to quantitative variation in $M C 4 R$ expression [97,100], with mechanisms such as poor cell-surface expression or intracellular retention of the mutant receptors $[101,102]$. It is also possible that genetic defects in the intracellular trafficking mechanisms, required to present MC4R on the cell surface, could also lead to human obesity [103]. Interestingly, human MC4R gene variants have also been associated with a lack of physical activity [104].

mc4r mRNA and MC4R protein is concentrated in the feeding areas of the PVN, DMH and lateral hypothalamus $[90,105]$. The obesity of the lethal yellow and viable yellow strains of mice is due to over-expressed agouti (with AgRP-like actions) in the hypothalamus, having an antagonistic effect at the MC3R and MC4R receptor [106]. $\mathrm{MC} 4 \mathrm{R}$ agonists reduce feeding in rodents, with antagonists having the opposite effect $[107,108]$. Finally, MC4R agonists administered intranasally decrease bodyweight in humans [109]. Also simple behavioural change, such as scheduling meal times, can significantly reduce the anorexic effect of MC3R/MC4R agonists in rats [110]. Perhaps the MC4R receptor does integrate the anorexigenic signal from leptin via the POMC neurones of the arcuate nucleus and brainstem. However, it is unlikely to be the only pathway. Double mutant $o b / o b m c 4 r / m c 4 r$ ko mice show partial leptin resistance when compared with $o b / o b$ strains, suggesting an alternate central anorexic signalling system for leptin exists [111].

POMC neurones in the arcuate nucleus, acting on other feeding areas such as the PVN via MC4R activation, may

Table 3: MC4R mRNA and protein expression and MC3R mRNA expression in CNS regions involved in appetite regulation. Potential targets for POMC and AgRP neurones (references indicated numerically).

\begin{tabular}{|c|c|c|c|}
\hline MCR locations: & MC4R mRNA & MC4R GFP expression & MC3R mRNA \\
\hline Arcuate nucleus & 90 & 105 & $93,114,118$ \\
\hline Brainstem & 90 & 105 & - \\
\hline PVN & 90,93 & 105 & 118 \\
\hline Lateral hypothalamus & 90 & 105 & 118 \\
\hline DMH & 90 & 105 & 118 \\
\hline SON & 90 & - & - \\
\hline VMH & 90 & 105 & 118 \\
\hline Periventricular nucleus & 90 & 105 & 118 \\
\hline Nucleus accumbens & 90 & 105 & - \\
\hline Amygdala & 90 & 105 & 118 \\
\hline
\end{tabular}


be the principal CNS conduit for leptin's peripheral satiety signal.

\section{$M C 3 R$, intra-arcuate connections and obesity}

Similarly one can review the evidence, either genetic or neuropharmacological, for the function of MC3R in the pathogenesis of obesity.

$m c 3 r$ ko mice are obese with increased fat mass and decreased lean body mass, but without hyperphagia, in contrast to $m c 4 r$ ko mice. However, mice lacking both $m c 3 r$ and $m c 4 r$ are more obese than $m c 4 r$ ko mice alone $[112,113]$. Also, the obesity of $m c 3 r$ ko mice is more dependent on fat intake than that of the mc4r ko mice [114]. Diet induced obesity in these two ko strains affects insulin-sensitivity more adversely in the $m c 4 r$ ko mice [114]. mc4r ko mice do not respond to the anorectic action of MTII [73]. MC3R gene variants are common in humans, but they are not associated with obesity [115]. However, MC3R may mediate different responses to leptin than MC4R. While leptin administration reduces food intake in $m c 4 r$ ko mice, $m c 3 r$ ko mice do not show an anorexic response to leptin. This suggests that the ability of leptin to reduce food consumption depends more upon MC3R, rather than MC4R [116].

The MC3R is particularly expressed on the arcuate nucleus, including on the POMC/CART neurones $[117,118]$ and the AgRP/NPY neurones [61] and is also more generally expressed in the CNS than the MC4R $[90,118] . \alpha-\mathrm{MSH}, \beta-\mathrm{MSH}$ and $\gamma_{2}-\mathrm{MSH}$ all activate different neuronal targets within this nucleus [42]. However, it should be noted that MC4R is found on the arcuate nucleus too $[90,105]$. There are intra-arcuate POMC connections, suggesting that MC3R may mediate an autofeedback mechanism in the arcuate nucleus (Tables 1 and 3; $[61,118,119])$. Administration of a specific MC3R agonist reduces the frequency of action potentials in POMC-containing neurones in the arcuate nucleus, which supports this hypothesis [62]. It is not yet known if any of these observations are important with regard to feeding behaviour, but they may be important with regard to overall control of POMC neural projections. Overall, the role of MC3R in feeding behaviour and obesity is less clear than for

MC4R.

\section{Proopiomelanocortin products and feeding}

It is clear that one or more of the POMC products is involved in the anorectic response, as mice lacking either the whole coding region of POMC or the whole POMC gene are obese $[8,9]$. While POMC is the precursor for at least three melanocortin peptides, $\alpha$-, $\beta$ - and $\gamma_{2}$-MSH (Figure 1$)$, it has been widely assumed that $\alpha-\mathrm{MSH}$ is the predominant ligand involved in appetite regulation in mammals, apart from humans $[41,120]$. $\beta$-MSH is not produced by rodents $[7,120]$. One impediment to comparative studies of melanocortin function is that it is very difficult to distinguish between the MSHs by immunocytochemistry, because of their similarity in core structure. Also, POMC neurones may release more than one peptide at any given synapse [42]. Finally, unprocessed POMC is found in human cerebrospinal fluid (CSF), at a concentration 100 fold higher than that of ACTH and may have a signalling role in the brain as well [121]. Obese leptin resistant $f a / f a$ rats and fasted (low leptin) wild type rats have lower CSF levels of POMC than fed rodents [122]. It should be noted that as leptin regulates POMC synthesis and release, it is difficult to dissect the role of POMC turnover in the CSF [122].

\section{$\alpha$-MSH and desacetyl- $\alpha-\mathbf{M S H}$}

$\alpha$-MSH suppresses feeding in free-feeding or fasted rodents, when administered centrally, as do its synthetic analogues containing the core MCR binding sequence $[42,106,123,124]$. Desacetyl- $\alpha-M S H$, in which the N-terminal serine remains unacetylated, is a major precursor of $\alpha-\mathrm{MSH}$ and is found widely in the brain [125]. Whilst not being shown to activate hypothalamic neurones in vivo [42], it binds to and activates both MC3R and MC4R in vitro and has an anorectic effect at high doses in vivo [123]. Leptin facilitates the acetylation of desacetyl- $\alpha$ MSH to the more active melanocortin, $\alpha$-MSH [126]. Perhaps a failure to acetylate desacetyl- $\alpha-\mathrm{MSH}$ in mammals could lead to obesity? This has not yet, however, been demonstrated.

\section{$\beta-\mathrm{MSH}$ and $\gamma-\mathrm{MSH}$}

In radioligand binding studies, $\beta$-MSH has a higher affinity for the MC4R than $\alpha-\mathrm{MSH}$, with $\gamma$-MSH having the lowest affinity. In contrast, $\gamma$-MSH binds to the MC3R with higher affinity than either $\alpha-\mathrm{MSH}$ or $\beta-\mathrm{MSH}$ [127]. It should be noted that binding of a ligand to a receptor does not necessarily correlate with biological activation of the cell expressing the receptor. Two independent studies have shown that $\beta$-MSH can have a suppressive effect on feeding in rats free-feeding or fasted for 24 hours $[123,124]$, but this has not been found in one study looking at rats fasted for 48 hours [42]. Perhaps this is because $\beta-\mathrm{MSH}$ is not produced physiologically in rodents $[7,120]$ and so any observed effects could be through pharmacological activation of the MC4R? [123,124,127] In a recent study in ko mice lacking pomc, central administration of $\alpha$-MSH, $\beta$-MSH and $\gamma$-MSH can all reduce food intake, but only $\alpha-\mathrm{MSH}$ actually reduces weight gain and significantly reverses the obese phenotype of the ko mouse [120]. A selective $\beta$-MSH-derived peptide agonist has been shown to decrease food intake and weight gain in diet-induced obese rats, but not MC4R-deficient mice [128]. This suggests that the anorectic pharmacological action of this $\beta$ MSH agonist in vivo is via the MC4R [128]. Recently, sev- 
eral missense mutations have been identified in human $\beta$ $\mathrm{MSH}$, associated with early-onset human obesity $[41,129]$, as well as a cleavage site mutation preventing processing of POMC to $\beta$-MSH, which is also associated with human obesity [40]. $\gamma_{2}$-MSH has a delayed anorectic effect in fasted rats [42]. These data are consistent with MC4R being the principal anorectic receptor in mammals, with either $\alpha-\mathrm{MSH}$ or $\beta-\mathrm{MSH}$ being the principal ligands depending upon species $[7,41,120]$. Perhaps the delayed feeding effect of $\gamma_{2}-\mathrm{MSH}$ reflects autostimulation of the POMC neurones projecting to the PVN, where POMC products bind to MC4R? Alternatively, it could reflect an inhibitory action via MC3R on NPY neurones in the arcuate nucleus [61]. It is possible that individual arcuate POMC projections in mammals release different combinations of peptides (MSHs or $\beta$-endorphin) at the different hypothalamic and extra-hypothalamic sites with which they synapse, as part of the complex integration of feeding behaviour in the CNS [42].

\section{Melanocortin-opioid interactions}

$\beta$-endorphin is another post-translational product of POMC and, together with the opioid peptides, the enkephalins and dynorphin, acts at $\mu$ - and $\kappa$-receptors to stimulate feeding [130-133]. Opioid antagonists block NPY induced feeding [134]. $\beta$-endorphin ko mice gain 10$15 \%$ more body weight than wild type after puberty [135]. Thus, there may be a more complementary interaction between the various POMC peptides in the regulation of feeding [136]. For example, it is possible that secretory vesicles could contain both MSHs and $\beta$-endorphin, which would have antagonistic effects on feeding. Immunocytochemistry has been used to show that there are synaptic connections between POMC and enkephalin neurones in the arcuate nucleus [137]. Using techniques already described in this article, the nucleus accumbens has been shown to have a POMC projection from the arcuate nucleus (Table 1 ; [93]). It also contains endogenous opioids which mediate the positive emotional response to palatable foods such as sugar and fat. This may be their main role in appetite control, as opioidevoked feeding is generally short lived [138].

\section{POMC and the paraventricular nucleus of the hypothalamus}

The PVN has both neuroendocrine and feeding roles. It has two major subdivisions, magnocellular and parvocellular, that fan either side of the roof of the 3rd ventricle. There is immunocytochemical evidence that many of the POMC neurones in the arcuate nucleus project to the PVN (Table 1 ; [93]) where the $m c 4 r$ mRNA is present in abundance (Table $3 ;[90])$. Surgical disruption of this pathway leads to obesity [58]. Activation of MC4Rs decreases body fat stores by reducing food intake and increasing energy expenditure. To identify which sites of $m c 4 r$ expression are most relevant for mediating these effects, mice were generated with a loxP-modified, null $m c 4 r$ allele (loxTB $m c 4 r$ ) that can be reactivated by Cre-recombinase [139]. Mice homozygous for the loxTB $m c 4 r$ allele do not express MC4Rs and are very obese [139]. Restoration of normal $m c 4 r$ expression in the PVN and a subpopulation of amygdala neurones, using sim1-Cre transgenic mice, prevented $60 \%$ of the obesity [139]. Notably, increased food intake was completely rescued while reduced energy expenditure was unaffected. These experiments suggest that MC4Rs in the PVN and/or the amygdala control food intake, but that MC4Rs elsewhere control energy expenditure [139]. All three MSHs, plus MTII, induce IEG expression in this area, although it is not known to what extent this reflects direct actions of the melanocortins (e.g., $\alpha$ $\mathrm{MSH}$ and $\beta-\mathrm{MSH}$ ) within the PVN or indirect activation (e.g., $\gamma_{2}-\mathrm{MSH}$ ) via the MC3R on the arcuate nucleus POMC neurones projecting to the PVN $[42,140]$. The PVN expresses LEPRB and is thus responsive to leptin $[18,19]$. Rats overfed postnatally, who are hyperleptinaemic, acquire altered electrophysiological responses in the PVN to $\alpha$-MSH, AgRP, MTII, CART, melanin-concentrating hormone (MCH) and NPY respectively [141]. Injection of $\alpha$ $\mathrm{MSH}$, but not $\beta$-endorphin, into the PVN reduces POMC gene expression in the arcuate nucleus, implying a negative feedback system involving melanocortins only [142].

\section{Nesfatin-I, $\alpha$-MSH and the PVN}

Nesfatin-1 is a novel satiety molecule that is processed from the nucleobindin2/nesfatin precursor molecule $[143,144]$ and its mRNA is distributed in hypothalamic nuclei including the arcuate nucleus and PVN [145]. Nesfatin- 1 concentrations are reduced in the PVN with fasting. Central administration of leptin does not alter nucleobindin2/nesfatin mRNA expression. Also, the satiety effect of nesfatin-1 is not altered in Zucker rats with an leprb mutation and prior administration of an anti-nesfatin-1 antibody does not block leptin-induced anorexia. This implies that leptin signalling is independent of nesfatin-1 signalling. In contrast, central administration of $\alpha$ MSH markedly stimulates nucleobindin2/nesfatin gene expression in the PVN [145]. Prior administration of the MC3R/MC4R antagonist SHU9119 abolishes nesfatin-1induced feeding suppression, but nesfatin-1 does not show any direct agonistic action on MC3R or MC4R. These observations suggest that nesfatin- 1 signalling is involved in a leptin-independent melanocortin signalling pathway in the hypothalamus.

It is clear that the arcuate nucleus to PVN circuit is fundamental in the transmission of the satiety message in the hypothalamus. 


\section{Neuroendocrine targets for POMC products in the PVN} Significant proportions of neurones activated by $\alpha-\mathrm{MSH}$, $\beta$-MSH and $\gamma_{2}-\mathrm{MSH}$ project outside the BBB and are thus presumed to be neuroendocrine in origin [42], such as CRF and TRH. Fasting suppresses CRF release, which is blocked by $\alpha$-MSH [146] and melanocortins can induce CRF gene transcription in some PVN CRF nerves expressing MC4R [147]. This suggests that CRF acts downstream of the melanocortin system. TRH release is elicited by $\alpha$ $\mathrm{MSH}$, whereas $\gamma$-MSH and AgRP inhibit TRH release. MC4R and MC3R agonists mimic the effect of $\alpha-\mathrm{MSH}$ and $\gamma$-MSH respectively [148]. This implies that hypothalamic TRH release is controlled by POMC and AgRP neurones. In the POMC ko mouse, there is reduced pituitary TSH and hypothalamic TRH production, but the thyroid gland compensates, with elevated plasma $\mathrm{T}_{3}$ and $\mathrm{T}_{4}$ [149]. These central effects of the melanocortins on the stress and thyroid axes suggest that POMC neurones may influence peripheral metabolism, which will in turn indirectly affect feeding behaviour.

\section{POMC and the lateral hypothalamus}

Damage to the lateral hypothalamus inhibits feeding, reducing body weight [150]. The lateral hypothalamus expresses leprb mRNA and is regulated by leptin throughout development [151]. Consistent with the anorexigenic role of hypothalamic POMC pathways, $\alpha-\mathrm{MSH}, \beta-\mathrm{MSH}$ and $\gamma_{2}-\mathrm{MSH}$ activate neurones in the more central hypothalamic structures that are associated with satiety, rather than in the lateral hypothalamus, which has an established role in feeding $[42,152]$. However, both $m c 3 r$ and $m c 4 r$ mRNA are located in the lateral hypothalamus (Table 3; $[90,118]$ ) and there is immunoreactive evidence of both POMC and AGRP fibres projecting from the arcuate nucleus to the lateral hypothalamus (Table 1 ; [93]), so the lack of response to the MSHs administered icv is perhaps surprising.

\section{$\mathrm{MCH}$ and POMC}

MCH causes hyperphagia, whether injected icv or directly into the arcuate nucleus, PVN and DMH. This is achieved in part by altering the balance of neuronal activity, favouring NPY/AgRP release and reducing $\alpha-\mathrm{MSH} / \mathrm{CART}$ release from arcuate neurones [152-154]. For example, in hypothalamic explant experiments injection of $\mathrm{MCH}$ into the hypothalamus increased the production of NPY and AgRP and decreased the production of MSH and CART, as measured by radioimmunoassay [153].

\section{Orexins and POMC}

Orexin expressing cells are located in the lateral, dorsal and perifornical nuclei. They innervate the arcuate nucleus, preoptic area, paraventricular nucleus of the thalamus, septal nuclei, locus coeruleus and DMX in the brainstem, as measured immunocytochemically. There is also immunocytochemical evidence that orexin neurones synapse with NPY/AgRP and POMC/CART neurones in the arcuate nucleus. Microinjection of orexins into the arcuate nucleus, PVN and lateral hypothalamus stimulates feeding [155-157]. It is possible to measure the action potential of individual living arcuate POMC neurones in mouse brain slices, identified by GFP transgenic tagging. Using whole cell patch clamp recordings, orexin suppresses the spontaneous firing in these neurones, suggesting that its appetite enhancing effects include an effect in suppressing hypothalamic POMC neuronal activity [158].

\section{POMC and the dorsomedial nucleus of the hypothalamus}

The DMH is an important leptin target, as it expresses both leprb mRNA and protein [18,19]. Lesioning experiments suggest that it has extensive projections to the PVN, particularly portions involved in autonomic control [159]. These experiments also show that lesions of this nucleus produce hypophagia and reduce linear growth [159]. Using techniques already described in this article, there is evidence of POMC projections from the arcuate nucleus to the DMH (Table $1 ;$ [93]) and both $m c 3 r$ and $m c 4 r$ mRNA are found in this nucleus (Table 3; $[90,118]$ ). Using a retrograde-labelled approach to measure axonal transport, there is evidence that some of these projections from the DMH to the PVN may be under the control of POMC neurones originating in the arcuate nucleus [160].

Despite the presence of the MC3R, only $\alpha-\mathrm{MSH}$ and $\beta$ MSH induce IEG expression in the DMH when administered icv. Very few of these neurones, which demonstrate increased IEG activity, project outside the BBB [42]. In $m c 4 r$ ko mice, or lethal yellow mice overexpressing agouti, NPY expression (but not galanin or POMC) is significantly elevated in the DMH. This suggests that POMC may normally inhibit NPY expression tonically in the DMH and that AgRP may be a determinant of NPY release physiologically [161]. The DMH has direct brainstem projections to the DMX, which has the highest density of MC4R in the brain $[90,162]$.

\section{POMC and the supraoptic nucleus of the hypothalamus}

The SON lies laterally in a bilateral position at the base of the hypothalamus. The SON and the mPVN contain oxytocin and vasopressin cells, which project to the posterior pituitary, where these hormones are released [3,163]. All three MSHs activate IEGs in the SON and coexpression with fluorogold suggests that all of these targets activated by $\alpha$-MSH and $\gamma_{2}-\mathrm{MSH}$, as well as the vast majority of those activated by $\beta$-MSH, project outside the blood-brain barrier in the rat [42]. $\beta$-MSH is not a physiological ligand of the MC4R in rodents which may explain this partial 
effect [42]. The effect of $\gamma_{2}-\mathrm{MSH}$ is rather surprising, given the presence of the MC4R and the absence of the MC3R in this nucleus (Table 3; [42]). Again, this may reflect indirect activation, perhaps via an arcuate nucleus POMC neuronal projection to the $\mathrm{SON}$, as evidenced by immunocytochemical detection of POMC fibres between these nuclei and in situ hybridisation for MC3R in the arcuate nucleus and MC4R in the SON (Table 1; $[90,93,118])$. CCK co-expression in oxytocin neurones in the SON occurs in rats on a normal diet only, rather than a high fat diet [164]. MC4R alone is expressed in the SON and MC4R ko mice are particularly prone to gaining weight on a high fat diet, even when compared with $o b / o b$ mice [165]. Perhaps POMC products acting on the MC4R, under dynamic antagonism from AgRP [93], form part of the CCK pathway in the SON involved with fat intake?

\section{POMC and the ventromedial nucleus of the hypothalamus}

The VMH lies close to the DMH, arcuate nucleus and third ventricle. The VMH has no known neuroendocrine projections [42], but lesioning experiments show that it is involved in feeding behaviour in the rat [166]. The projection from the arcuate nucleus to the $\mathrm{VMH}$ is very sparse and very few of these fibres are POMC neurones on immunocytochemistry (Table 1 ; [93]). Despite this, $m c 3 r$ and $m c 4 r$ mRNA are abundant (Table 3; [90,118]). MTII increases neuronal firing in the $\mathrm{VMH}$ in vitro and this effect is lessened by prior food deprivation [167]. Perhaps free POMC in the CNS has a true neuroendocrine role and is post-translationally processed locally by the VMH? [121] This could explain the extensive expression of $m c 3 r$ and $m c 4 r$, despite the very limited POMC axonal presence in the $\mathrm{VMH}$.

\section{Brain-derived neurotrophic factor, TrkB and POMC neurones}

Brain-derived neurotrophic factor (BDNF) and its receptor, TrkB, control neurodevelopment and synaptic plasticity. TrkB-deficient humans show learning difficulties and severe obesity [168]. bdnf-deficient heterozygous mice are obese, with high leptin and insulin levels which correct with diet alone [169]. bdnf mRNA or protein is expressed in the $\mathrm{VMH}, \mathrm{DMH}$ and lateral hypothalamus, but not the arcuate nucleus $[169,170]$. Its expression is reduced in the $\mathrm{VMH}$ of lethal yellow mice, whereas administration of MTII increases BDNF expression in the VMH of wild type mice. BDNF suppresses feeding and weight gain in MC4R ko mice, so its anorexic actions lie downstream of POMC. It is unlikely that BDNF modulates either CART/POMC or NPY/AgRP neurones in the arcuate nucleus as there is no trkb receptor mRNA expressed in this nucleus [170].

\section{POMC and the periventricular nucleus of the hypothalamus}

Cafeteria diet-induced obese rats have been shown to have increased somatostatin protein content and gene expression in the periventricular nucleus [171]. Using a double-labelled immunocytochemical approach, arcuate nucleus POMC neurones have been shown to project to the majority of somatostatin perikarya in the periventricular nucleus [172]. This implies that the effects of somatostatin on growth and body composition are under the influence of the melanocortins [172]. Similarly, somatostatin receptors are located on POMC arcuate nucleus neurones, suggesting bidirectional communication [172]. These observations link the hypothalamic functions of appetite and growth regulation.

\section{POMC, the nucleus accumbens and the amygdala}

There is immunocytochemical evidence that the nucleus accumbens of the forebrain receives both POMC and AgRP projections from the arcuate nucleus (Table 1 ; [93]), as well as a dopamine projection which mediates the reinforcing effects of stimulants, like cocaine, amphetamine, nicotine and caffeine [173-175]. Microinjection of muscimol, a $\mathrm{GABA}_{\mathrm{A}}$ receptor agonist, into the nucleus accumbens, increases feeding. This is associated with activation of orexin neurones (but not $\mathrm{MCH}$ ) in the lateral hypothalamus and the activation of the NPY/AgRP projection and inhibition of the POMC/CART projection in the Arc [176]. This may be a mechanism for the appetite modulating effects of cocaine, amphetamine, nicotine and caffeine.

The amygdala, located in the mid-temporal lobe, assigns emotional significance to sensory information, such as fear-related responses [177]. It receives auditory and other efferents from the thalamus, cortex and hypothalamus. In turn, it projects to brainstem and hypothalamic regions that regulate autonomic, endocrine and feeding responses [178]. For example, there is evidence from immunocytochemistry that it receives POMC/CART and AgRP/NPY projections from the arcuate nucleus (Table 1; [93]). The release of CRF and bombesin-like peptides in the amygdala is markedly increased by both stress and feeding [179]. These CRF and bombesin amygdala neurones could be influenced by arcuate POMC or AgRP projections to the amygdala triggered by either stress or alteration in nutritional balance [93].

\section{Discussion}

Polygenic traits, such as obesity, result from complex combinations of multiple contributing genes [180], environmental factors [181], or gene-environment interactions [182]. In 1980, $8 \%$ of women and $6 \%$ of men in England were obese, with a body-mass index greater more 
than $30 \mathrm{~kg} / \mathrm{m}^{2}$. By 1998 , the proportion of obese subjects had increased to $21 \%$ of women and $17 \%$ of men, suggesting perhaps that environment is a key factor [183]. However, several rare monogenic human obesity syndromes have recently been described. These include deficiencies of leptin, LEPRB, single-minded 1 (SIM1), PC1, $P O M C$ and MC4R deficiency [184]. All of these syndromes are associated with hyperphagia. The last three of these gene defects produce altered protein products involved in POMC neuronal transmission (Figure 1). The other three are key factors interacting with the central melanocortin pathway. Leptin binding to LEPRB is the main peripheral hormonal stimulus to arcuate POMC neurones [11] and SIM1 is specifically involved in the development of the PVN [185]. The PVN is the destination of the principal arcuate POMC projection involved in suppressing feeding $[47,62,93]$. sim 1 heterozygous deficient mice have a similar phenotype to MC4R deficient and lethal yellow mice, with obesity resistant to the effects of melanocortins [186]. Also, when the melanocortin antagonist AgRP is mutated in either rodents or humans, it leads to thinness [53-55]. Thus, there is considerable human and murine genetic evidence for the involvement of the central melanocortin pathways in the control of appetite [7]. Could genetic variation in this system (and that of related interacting molecules) be part of the polygenic tendency to obesity in humans $[7,40,41,44$ $46,129,180,184]$ ? MC4R deficiency is the commonest of all the human single-gene defects causing obesity, responsible for $5 \%$ of all severe cases [7]. POMC heterozygosity has also been found to correlate with obesity in mice and humans, to a lesser extent than the homozygous state $[9,187]$. POMC neurones may mediate a central anorexic signal in proportion to body adipocyte reserves, possibly via the actions of $\beta-\mathrm{MSH}$ on the MC4R in humans $[41,129]$.

\section{Conclusion}

In summary, the likely model for the melanocortin regulation of feeding is that the AgRP signal in the arcuate nucleus fluctuates to modulate a more constant POMC signal $[57,59]$, which is a function of the relatively steady hormonal level of leptin [49]. POMC products may be released differentially in the different hypothalamic and extra-hypothalamic sites involved with feeding in the CNS [42], which could lead to subtle variations in the anorexic signal being transmitted. This may or may not be independent of leptin signalling.

\section{Competing interests}

The author(s) declare that they have no competing interests.

\section{Authors' contributions}

GWMM conceived and wrote this review article. The author read and approved the final manuscript.

\section{Acknowledgements}

Financial support from the Wellcome Trust, Sackler Foundation and St. John's College, University of Cambridge is gratefully acknowledged.

\section{References}

I. Millington GWM: Pro-opiomelanocortin (POMC): the cutaneous roles of its melanocortin products and receptors. Clin Experimental Dermatol 2006, 31:407-4I2.

2. Theogaraj E, John CD, Christian HC, Morris JF, Smith SF, Buckingham JC: Perinatal glucocorticoid treatment produces molecular, functional, and morphological changes in the anterior pituitary gland of the adult male rat. Endocrinology 2005, | 46:4804-48| 3.

3. Sawchenko PE, Brown ER, Chan RKW, Ericsson A, Li H-Y, Roland BL, Kovács $\mathrm{KJ}$ : The paraventricular nucleus of the hypothalamus and the functional neuroanatomy of visceromotor responses to stress. Prog Brain Res 1996, 107:201-222.

4. Catania A, Airaghi L, Colombo G, Lipton JM: $\alpha$-melanocyte-stimulating hormone in normal human physiology and disease states. Trends Endocrinol Metab 2000, I I :304-308.

5. Millington GWM, Buckingham JC: Thymic peptides and neuroendocrine immune communication. I Endocrinol 1992, 133:163-168.

6. Van der Ploeg LHT, Martin WJ, Howard AD, Nargund RP, Austin CP, Guan X, Drisko J, Cashen D, Sebhat I, Patchett AA, Figueroa DJ, DiLella AG, Connolly BM, Weinberg DH, Tan CP, Palyha OC, Pong S-S, MacNeil T, Rosenblum C, Vongs A, Tang R, Yu H, Sailer AW, Fong TM, Huang C, Tota MR, Chang RS, Stearns R, Tamvakopoulos C, Christ G, Drazen DL, Spar DB, Nelson J, Maclntyre DE: A role for the melanocortin 4receptor in sexual function. Proc Natl Acad Sci USA 2002, 99: I I38 I- I I386.

7. Coll AP, Farooqi IS, Challis BG, Yeo GS, O'Rahilly S: Proopiomelanocortin and energy balance: insights from human and murine genetics. J Clin Endocrinol Metab 2004, 89:2557-2562.

8. Yaswen L, Diehl N, Brennan MD, Hochgeschwender U: Obesity in the mouse model of pro-opiomelanocortin deficiency responds to peripheral melanocortin. Nat Med 1999, 5:1066-1070.

9. Challis BG, Coll AP, Yeo GSH, Pinnock SB, Dickson SL, Thresher RR, Dixon J, Zahn D, Rochford J, White A, Oliver RL, Millington GWM, Aparicio SA, Colledge WH, Russ AP, Carlton MB, O'Rahilly S: Mice lacking pro-opiomelanocortin are sensitive to high-fat feeding but respond normally to the acute anorectic effects of

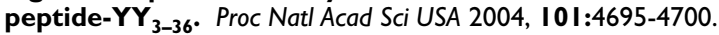

10. Jobst EE, Enriori PJ, Cowley MA: The electrophysiology of feeding circuits. Trends Endocrinol Metab 2004, I 5:488-499.

II. Cone RD: Anatomy and regulation of the central melanocortin system. Nat Neurosci 2005, 8:57I-578.

12. Spiegelman BM, Flier JS: Obesity and the regulation of energy balance. Cell 2001, 104:531-543.

13. Flier JS: Obesity wars: molecular progress confronts an expanding epidemic. Cell 2004, I | 6:337-350.

14. Schwartz MW, Woods SC, Porte D, Seeley RJ, Baskin DG: Central nervous system control of food intake. Nature 2000, 404:66 I-67I.

15. Schwartz MW, Porte D: Diabetes, obesity, and the brain. Science 2005, 307:375-379.

16. Stanley S, Wynne K, McGowan B, Bloom SR: Hormonal regulation of food intake. Physiol Rev 2005, 85: I I3I-I I58.

17. Fry M, Hoyda ED, Ferguson AV: Making sense of it: roles of the sensory circumventricular organs in feeding and regulation of energy homeostasis. Exp Biol Med 2007, 232(I): | 4-26.

18. Elmquist JK, Bjørbæk C, Ahima RS, Flier JS, Saper CB: Distributions of leptin receptor mRNA isoforms in the rat brain. J Comp Neurol 1998, 395:535-547.

19. Håkansson M-L, Brown H, Ghilardi N, Skoda RC, Meister B: Leptin receptor immunoreactivity in chemically defined target neurons of the hypothalamus. J Neurosci 1998, I 8:559-572. 
20. Cheung CC, Clifton DK, Steiner RA: Proopiomelanocortin neurons are direct targets for leptin in the hypothalamus. Endocrinology 1997, I 38:4489-4492.

21. Munzberg H, Huo L, Nillni EA, Hollenberg AN, Bjorbaek C: Role of signal transducer and activator of transcription 3 in regulation of hypothalamic proopiomelanocortin gene expression by leptin. Endocrinology 2003, |44:2I $2|-2| 3 \mid$.

22. Drouin J, Nemer M, Charron J, Gagner J-P, Jeannotte L, Sun YL, Therrien $M$, Tremblay $Y$ : Tissue specific activity of the pro-opiomelanocortin (POMC) gene and repression by glucorticoids. Genome 1989, 3 1:510-519.

23. de Souza FS, Santangelo AM, Bumaschny V, Avale ME, Smart JL, Low $M J$, Rubinstein $M$ : Identification of neuronal enhancers of the proopiomelanocortin gene by transgenic mouse analysis and phylogenetic footprinting. Mol Cell Biol 2005, 25:3076-3086.

24. Allen RG, Orwell E, Kendall JW, Herbert E, Paxton H: The distribution of forms of adrenocorticotropin and beta-endorphin in normal, tumorous, and autopsy human pituitary tissue: virtual absence of I $3 \mathbf{K}$ adrenocorticotropin. J Clin Endocrinol Metab | 980, 5 |:376-380.

25. Allen RG, Hatfield JM, Stack J, Ronnekleiv O: Posttranslational processing of proopiomelanocortin (POMC)-derived peptides during fetal monkey pituitary development. Adrenocorticotropin (ACTH) and $\alpha$-melanotropins ( $\alpha$-MSHs). Dev Biol 1988, I 26:164-172.

26. Bateman A, Solomon S, Bennett HPJ: Post-translational modification of bovine pro-opiomelanocortin. J Biol Chem 1990, 265:22130-22136.

27. Cool DR, Normant E, Shen F, Chen H-C, Pannell L, Zhang Y, Loh YP: Carboxypeptidase $E$ is a regulated secretory pathway sorting receptor: genetic obliteration leads to endocrine disorders in Cpefat mice. Cell 1997, 88:73-83.

28. Day R, Schafer MK-H, Watson SJ, Chrétien M, Seidah NG: Distribution and regulation of the prohormone convertases $\mathrm{PCI}$ and PC2 in the rat pituitary. Mol Endocrinol 1992, 6:485-497.

29. Seidah NG, Fournier H, Boileau G, Benjannet S, Rondeau N, Chrétien $M$ : The cDNA structure of the porcine pro-hormone convertase PC2 and the comparative processing by PCI and PC2 of the N-terminal glycopeptide segment of porcine POMC. FEBS Lett 1992, 3 1 0:235-239.

30. Zhou A, Bloomquist BT, Mains RE: The prohormone convertases PCI and PC2 mediate district endoproteolytic cleavages in a strict temporal order during proopiomelanocortin biosynthetic processing. J Biol Chem 1993, 268: I763-I769.

31. Evans VR, Manning AB, Bernard LH, Chronwall BM, Millington WR: $\alpha$-melanocyte-stimulating hormone and $\boldsymbol{N}$-acetyl- $\beta$-endorphin immunoreactivities are localized in the human pituitary but are not restricted to the zona intermedia. Endocrinology 1994, I 34:97-106.

32. Paquet L, Zhou A, Chang EY, Mains RE: Peptide biosynthetic processing: distinguishing prohormone convertases $\mathrm{PCI}$ and PC2. Mol Cell Endocrinol 1996, I 20:161-168.

33. Bertagna X: Proopiomelanocortin-derived peptides. Endocrinol Metab Clin North Am 1994, 23:467-485.

34. Miller R, Aaron W, Toneff T, Vishnuvardhan D, Beinfeld MC, Hook VYH: Obliteration of $\alpha$-melanocyte-stimulating hormone derived from POMC in pituitary and brains of PC2-deficient mice. J Neurochem 2003, 86:556-563.

35. Dong W, Marcinkiewicz M, Vieau D, Chrétien M, Seidah NG, Day R: Distinct mRNA expression of the highly homologous convertases PC5 and PACE4 in the rat brain and pituitary. J Neurosci 1995, 15:1778-1796.

36. Loh YP, Parish DC, Tuteja R: Purification and characterization of a paired basic residue-specific pro-opiomelanocortin converting enzyme from bovine pituitary intermediate lobe secretory vesicles. J Biol Chem 1985, 260:7194-7205.

37. Pritchard LE, Turnbull AV, White A: Pro-opiomelanocortin processing in the hypothalamus: impact on melanocortin signalling and obesity. J Endocrinol 2002, I 72:4I I-42I.

38. Jackson RS, Creemers JWM, Ohagi S, Raffin-Sanson M-L, Sanders L, Montague CT, Hutton JC, O'Rahilly S: Obesity and impaired prohormone processing associated with mutations in the human prohormone convertase Igene. Nat Genet 1997, 1 6:303-306.

39. Gabreels BA, Swaab DF, de Kleijn DP, Seidah NG, Van de Loo JW, Van de Ven WJ, Martens GJ, van Leeuwen FW: Attenuation of the polypeptide 7B2, prohormone convertase PC2, and vasopressin in the hypothalamus of some Prader-Willi patients: indications for a processing defect. J Clin Endocrinol Metab 1998, 83:591-599.

40. Challis BG, Pritchard LE, Creemers JWM, Delplanque J, Keogh JM, Luan J, Wareham NJ, Yeo GSH, Bhattacharyya S, Froguel P, White A, Farooqi IS, O'Rahilly S: A missense mutation disrupting a dibasic prohormone processing site in pro-opiomelanocortin (POMC) increases susceptibility to early-onset obesity through a novel molecular mechanism. Hum Mol Genet 2002, I I:1997-2004.

41. Lee YS, Challis BG, Thompson DA, Yeo GS, Keogh JM, Madonna ME, Wraight V, Sims M, Vatin V, Meyre D, Shield J, Burren C, Ibrahim Z, Cheetham T, Swift P, Blackwood A, Hung CC, Wareham NJ, Froguel P, Millhauser GL, O'Rahilly S, Farooqi IS: A POMC variant implicates beta-melanocyte-stimulating hormone in the control of human energy balance. Cell Metab 2006, 3: I35-140.

42. Millington GWM, Tung YCL, Hewson AK, O'Rahilly S, Dickson SL: Differential effects of $\alpha-, \beta-$ and $\gamma 2$-melanocyte-stimulating hormones on hypothalamic neuronal activation and feeding in the fasted rat. Neuroscience 200I, 1 08:437-445.

43. Hinney A, Becker I, Heibült O, Nottebom K, Schmidt A, Ziegler A, Mayer H, Siegfried W, Blum WF, Remschmidt H, Hebebrand J: Systematic mutation screening of the pro-opiomelanocortin gene: identification of several genetic variants including three different insertions, one nonsense and two missense point mutations in probands of different weight extremes. J Clin Endocrinol Metab 1998, 83:3737-374I.

44. Comuzzie AG, Hixson JE, Almasy L, Mitchell BD, Mahaney MC, Dyer TD, Stern MP, MacCluer JW, Blangero J: A major quantitative trait locus determining serum leptin levels and fat mass is located on human chromosome 2. Nat Genet I997, I 5:273-276.

45. Hixson JE, Almasy L, Cole S, Birnbaum S, Mitchell BD, Mahaney MC, Stern MP, MacCluer JW, Blangero J, Comuzzie AG: Normal variation in leptin levels is associated with polymorphisms in the proopiomelanocortin gene, POMC. J Clin Endocrinol Metab 1999, 84:3187-3191.

46. Getting SJ: Targeting melanocortin receptors as potential novel therapeutics. Pharmacol Ther 2006, I I I: I- I5.

47. Bouret SG, Draper SJ, Simerly RB: Formation of projection pathways from the arcuate nucleus of the hypothalamus to hypothalamic regions implicated in the neural control of feeding behaviour in mice. J Neurosci 2004, 24:2797-2805.

48. Dhillo WS, Small CJ, Stanley SA, Jethwa PH, Seal LJ, Murphy KG, Ghatei MA, Bloom SR: Hypothalamic interactions between neuropeptide $Y$, agouti-related protein, cocaine- and amphetamine-regulated transcript and alpha-melanocytestimulating hormone in vitro in male rats. I Neuroendocrinol 2002, 14:725-730.

49. Mizuno TM, Kleopoulos SP, Bergen HT, Roberts JL, Priest CA, Mobbs $\mathrm{CV}$ : Hypothalamic pro-opiomelanocortin mRNA is reduced by fasting and in ob/ob and $d b / d b$ mice, but is stimulated by leptin. Diabetes 1998, 47:294-297.

50. Hagan MM, Rushing PA, Schwartz MW, Yagaloff KA, Burn P, Woods SC, Seeley RJ: Role of the CNS melanocortin system in the response to overfeeding. I Neurosci 1999, 19:2362-2367.

5I. Wilding JPH, Ajala MO, Lambert PD, Bloom SR: Additive effects of lactation and food restriction to increase hypothalamic neuropeptide $Y$ mRNA in rats. J Endocrinol 1997, I 52:365-369.

52. Garcia de Yebenes E, Li S, Fournier A, St-Pierre S, Pelletier G: Regulation of proopiomelanocortin gene expression by neuropeptide $Y$ in the rat arcuate nucleus. Brain Res 1995, 674: I I2-I 16.

53. Haskell-Luevano C, Chen P, Li C, Chang K, Smith MS, Cameron JL, Cone RD: Characterization of the neuroanatomical distribution of agouti-related protein immunoreactivity in the rhesus monkey and the rat. Endocrinology 1999, I40:1408-1415.

54. Gropp E, Shanabrough M, Borok E, Xu AW, Janoschek R, Buch T, Plum L, Balthasar N, Hampel B, Waisman A, Barsh GS, Horvath TL, Bruning JC: Agouti-related peptide-expressing neurons are mandatory for feeding. Nat Neurosci 2005, 8: |289-|29|.

55. Marks DL, Boucher N, Lanouette CM, Perusse L, Brookhart G, Comuzzie AG, Chagnon YC, Cone RD: Ala67Thr polymorphism in the Agouti-related peptide gene is associated with inherited leanness in humans. Am J Med Genet 2004, I 26:267-27I.

56. Larsen PJ, Vrang N, Tang-Christensen M, Jensen PB, Hay-Schmidt A, Romer J, Bjerre-Knudsen L, Kristensen P: Ups and downs for neu- 
ropeptides in body weight homeostasis: pharmacological potential of cocaine amphetamine regulated transcript and pre-proglucagon-derived peptides. Eur J Pharmacol 2002, 440: $159-172$.

57. Pinto S, Roseberry AG, Liu H, Diano S, Shanabrough M, Cai X, Friedman JM, Horvath TL: Rapid rewiring of arcuate nucleus feeding circuits by leptin. Science 2004, 304: I I0-I I 5.

58. Bell ME, Bhatnagar S, Akana SF, Choi S, Dallman MF: Disruption of arcuate/paraventricular nucleus connections changes body energy balance and response to acute stress. J Neurosci 2000, 20:6707-67।3.

59. Takahashi KA, Cone RD: Fasting induces a large, leptin-dependent increase in the intrinsic action potential frequency of orexigenic arcuate nucleus neuropeptide Y/agouti-related protein neurons. Endocrinology 2005, 146: 1043-1047.

60. Raposinho PD, White RB, Aubert ML: The melanocortin agonist Melanotan-II reduces the orexigenic and adipogenic effects of neuropeptide Y (NPY) but does not affect the NPY-driven suppressive effects on the gonadotropic and somatotropic axes in the male rat. J Neuroendocrinol 2003, 15:173-181.

61. Mounien L, Bizet P, Boutelet I, Vaudry H, Jegou S: Expression of melanocortin MC3 and MC4 receptor MRNAs by neuropeptide $\mathbf{Y}$ neurons in the rat arcuate nucleus. Neuroendocrinology 2006, 82: $164-170$

62. Cowley MA, Smart JL, Rubinstein M, Cerdán MG, Diano S, Horvath TL, Cone RD, Low MJ: Leptin activates anorexigenic POMC neurons through a neural network in the arcuate nucleus. Nature 200I, 4I I:480-484.

63. Rao TL, Kokare DM, Sarkar S, Khisti RT, Chopde CT, Subhedar N: GABAergic agents prevent alpha-melanocyte stimulating hormone induced anxiety and anorexia in rats. Pharmacol Biochem Behav 2003, 76:417-423.

64. Roseberry AG, Liu H, Jackson AC, Cai X, Friedman JM: Neuropeptide $Y$-mediated inhibition of proopiomelanocortin neurons in the arcuate nucleus shows enhanced desensitization in obl ob mice. Neuron 2004, 41:71 I-722.

65. Hentges ST, Nishiyama M, Overstreet LS, Stenzel-Poore M, Williams JT, Low MJ: GABA release from proopiomelanocortin neurons. J Neurosci 2004, 24: 1578-1583.

66. Meister B, Gomuc B, Suarez E, Ishii Y, Durr K, Gillberg L: Hypothalamic proopiomelanocortin (POMC) neurons have a cholinergic phenotype. Eur J Neurosci 2006, 24:273 I-2740.

67. Collin M, Backberg M, Ovesjo ML, Fisone G, Edwards RH, Fujiyama F, Meister B: Plasma membrane and vesicular glutamate transporter mRNAs/proteins in hypothalamic neurons that regulate body weight. Eur J Neurosci 2003, 18: | 265-1278.

68. Kiss J, Csaba Z, Csaki A, Halasz B: Glutaminergic innervation of neuropeptide $Y$ and pro-opiomelanocortin-containing neurons in the hypothalamic arcuate nucleus of the rat. Eur J Neurosci 2005, 2I:2।II-2II9.

69. Dinulescu DM, Cone RD: Agouti and agouti-related protein: analogies and contrasts. J Biol Chem 2000, 275:6695-6698.

70. Pritchard LE, White A: Agouti-related protein: more than a melanocortin-4 receptor agonist? Peptides 2005, 26: I759- I 770.

71. Nijenhuis WA, Oosterom J, Adan RA: AgRP (83-132) acts as an inverse agonist on the human-melanocortin-4 receptor. $\mathrm{Mol}$ Endocrinol 200I, 15:164-171.

72. Day DE, Bartness TJ: Agouti-related protein increases food hoarding more than food intake in Siberian hamsters. Am J Physiol 2004, 286:R38-45.

73. Marsh DJ, Hollopeter G, Huszar D, Laufer R, Yagaloff KA, Fisher SL, Burn P, Palmiter RD: Response of melanocortin-4 receptordeficient mice to anorectic and orexigenic peptides. Nat Genet 1999, 21:119-122.

74. Ollmann MM, Wilson BD, Yang Y-K, Kerns JA, Chen Y, Gantz I, Barsh GS: Antagonism of central melanocortin receptors in vitro and in vivo by agouti-related protein. Science 1997, 278: $135-138$.

75. Shutter JR, Graham M, Kinsey AC, Scully S, Luthy R, Stark KL: Hypothalamic expression of ART, a novel gene related to agouti is upregulated in obese and diabetic mutant mice. Genes Dev 1997, I I:593-602.

76. Thornton JE, Cheung CC, Clifton DK, Steiner RA: Regulation of hypothalamic proopiomelanocortin mRNA by leptin in obl ob mice. Endocrinology 1997, 138:5063-5066.
77. Batterham RL, Cohen MA, Ellis SM, Le Roux CW, Withers DJ, Frost GS, Ghatei MA, Bloom SR: Inhibition of food intake in obese subjects by peptide $Y_{3-36}$. N Engl J Med 2003, 349:94I-948.

78. Batterham RL, Cowley MA, Small C], Herzog H, Cohen MA, Dakin CL, Wren AM, Brynes AE, Low MJ, Ghatei MA, Cone RD, Bloom SR: Gut hormone $\mathrm{PYY}_{3-36}$ physiologically inhibits food intake. Nature 2002, 4I 8:650-654.

79. Challis BG, Pinnock SB, Coll AP, Carter RN, Dickson SL, O'Rahilly S: Acute effects of $P Y Y_{3-36}$ on food intake and hypothalamic neuropeptide expression in the mouse. Biochem Biophys Res Commun 2003, 3 II:915-919.

80. Nonaka N, Shioda S, Niehoff ML, Banks WA: Characterization of blood-brain barrier permeability to $\mathrm{PYY}_{3-36}$ in the mouse. J Pharmacol Exp Ther 2003, 306:948-953.

8I. Ghamari-Langroudi M, Colmers WF, Cone RD: PYY3-36 inhibits the action potential firing activity of POMC neurons of arcuate nucleus through postsynaptic Y2 receptors. Cell Metab 2005, 2: 191-199.

82. Halatchev IG, Ellacott KLJ, Fan W, Cone RD: Peptide YY $_{3-36}$ inhibits food intake in mice through a melanocortin- 4 receptorindependent mechanism. Endocrinology 2004, 145:2585-2590.

83. Hahm S, Fekete C, Mizuno TM, Windsor J, Yan H, Boozer CN, Lee C. Elmquist JK, Lechan RM, Mobbs CV, Salton SRJ: VGF is required for obesity induced by diet, gold thioglucose treatment, and agouti and is differentially regulated in pro-opiomelanocortin- and neuropeptide Y-containing arcuate neurons in response to fasting. J Neurosci 2002, 22:6929-6938.

84. Barrett P, Ross AW, Balik A, Littlewood PA, Mercer JG, Moar KM, Sallmen T, Kaslin J, Panula P, Schuhler S, Ebling FJ, Ubeaud C, Morgan PJ: Photoperiodic regulation of histamine $\mathrm{H} 3$ receptor and VGF messenger ribonucleic acid in the arcuate nucleus of the Siberian hamster. Endocrinology 2005, 146: 1930-1939.

85. Bedecs K, Berthold M, Bartfai T: Galanin - 10 years with a neuroendocrine peptide. Int J Biochem Cell Biol 1995, 27:337-349.

86. Mitchell V, Habert-Ortoli E, Epelbaum J, Aubert J-P, Beauvillain J-C: Semiquantitative distribution of galanin-receptor (GAL-RI) mRNA-containing cells in the male rat hypothalamus. Neuroendocrinology 1997, 66: 160-172.

87. Poulain P, Decroca N, Mitchell V: Direct inhibitory action of galanin on hypothalamic arcuate nucleus neurones expressing galanin receptor Gal-RI mRNA. Neuroendocrinology 2003, 78:105-117.

88. Fan W, Ellacott KL, Halatchev IG, Takahashi K, Yu P, Cone RD: Cholecystokinin-mediated suppression of feeding involves the brainstem melanocortin system. Nat Neurosci 2004, 7:335-336.

89. Appleyard SM, Bailey TW, Doyle MW, Jin YH, Smart JL, Low MJ, Andresen MC: Proopiomelanocortin neurons in nucleus tractus solitarius are activated by visceral afferents: regulation by cholecystokinin and opioids. J Neurosci 2005, 25:3578-3585.

90. Mountjoy KG, Mortrud MT, Low MJ, Simerly RB, Cone RD: Localization of the melanocortin-4 receptor (MC4-R) in neuroendocrine and autonomic control circuits in the brain. Mol Endocrinol 1994, 8: I298-। 308.

91. Zheng H, Patterson LM, Phifer CB, Berthoud HR: Brain stem melanocortinergic modulation of meal size and identification of hypothalamic POMC projections. Am J Physiol 2005, 289(I):R247-R258

92. Sachot C, Rummel C, Bristow AF, Luheshi GN: The role of the vagus nerve in mediating the long-term anorectic effects of leptin. J Neuroendocrinol 2007, 19:250-26I.

93. Bagnol D, Lu X-Y, Kaelin CB, Day HEW, Ollmann M, Gantz I, Akil H, Barsh GS, Watson SJ: Anatomy of an endogenous antagonist: relationship between agouti-related protein and proopiomelanocortin in brain. J Neurosci 1999, 19(18):RC26-.

94. Grill HJ, Schwartz MW, Kaplan JM, Foxhall JS, Breininger J, Baskin DG: Evidence that the caudal brainstem is a target for the inhibitory effect of leptin on food intake. Endocrinology 2002, 143:239-246.

95. Huo L, Grill HJ, Bjorbaek C: Divergent regulation of proopiomelanocortin neurons by leptin in the nucleus of the solitary tract and in the arcuate hypothalamic nucleus. Diabetes 2006, 55:567-573.

96. Shigemura N, Ohta R, Kusakabe $Y$, Miura H, Hino A, Koyano K, Nakashima $K$, Ninomiya $Y$ : Leptin modulates behavioral 
responses to sweet substances by influencing peripheral taste structures. Endocrinology 2004, 145:839-847.

97. Huszar D, Lynch CA, Fairchild-Huntress V, Dunmore JH, Fang $Q$, Berkemeier LR, Gu W, Kesterson RA, Boston BA, Cone RD, Smith FJ, Campfield LA, Burn P, Lee F: Targeted disruption of the melanocortin-4 receptor results in obesity in mice. Cell 1997, 88:|3|-|4|.

98. Vaisse C, Clement K, Guy-Grand B, Froguel P: A frameshift mutation in human MC4R is associated with a dominant form of obesity. Nat Genet 1998, 20: I I3-I I4.

99. Yeo GSH, Farooqi IS, Aminian S, Halsall DJ, Stanhope RG, O'Rahilly S: A frameshift mutation in MC4R associated with dominantly inherited human obesity. Nat Genet 1998, 20: I I I-I I2.

100. Cone RD: The central melanocortin system and energy homeostasis. Trends Endocrinol Metab 1999, 10:211-216.

101. Lubrano-Berthelier C, Durand E, Dubern B, Shapiro A, Dazin P, Weill J, Ferron C, Froguel $P$, Vaisse $C$ : Intracellular retention is a common characteristic of childhood obesity-associated MC4R mutations. Hum Mol Genet 2003, I 2:145-153.

102. Nijenhuis WAJ, Garner KM, van Rozen RJ, Adan RAH: Poor cell surface expression of human melanocortin-4 receptor mutations associated with obesity. I Biol Chem 2003, 278:22939-22945

103. Mohammad S, Baldini G, Granell S, Narducci P, Martelli AM, Baldini G: Constitutive traffic of melanocortin-4 receptor in Neuro2A cells and immortalized hypothalamic neurons. J Biol Chem 2007, 282:4963-4974.

104. Loos RJ, Rankinen T, Tremblay A, Perusse L, Chagnon Y, Bouchard C: Melanocortin-4 receptor gene and physical activity in the Quebec Family Study. Int J Obes 2005, 29:420-428.

105. Liu H, Kishi T, Roseberry AG, Cai X, Lee CE, Montez JM, Friedman JM, Elmquist JK: Transgenic mice expressing green fluorescent protein under the control of the melanocortin- 4 receptor promoter. I Neurosci 2003, 23:7|43-7|54.

106. Lu D, Willard D, Patel IR, Kadwell S, Overton L, Kost T, Luther M, Chen W, Woychik RP, Wilkison WO, Cone RD: Agouti protein is an antagonist of the melanocyte-stimulating-hormone receptor. Nature 1994, 71:799-802.

107. Fan W, Boston BA, Kesterson RA, Hruby VJ, Cone RD: Role of melanocortinergic neurons in feeding and the agouti obesity syndrome. Nature 1997, 385:165-168.

108. Benoit SC, Schwartz MW, Lachey JL, Hagan MM, Rushing PA, Blake KA, Yagaloff KA, Kurylko G, Franco L, Danhoo W, Seeley RJ: A novel selective melanocortin-4 receptor agonist reduces food intake in rats and mice without producing aversive consequences. J Neurosci 2000, 20:3442-3448.

109. Fehm HL, Smolnik R, Kern W, McGregor GP, Bickel U, Born J: The melanocortin melanocyte-stimulating hormonel adrenocorticotropin $_{4-10}$ decreases body fat in humans. J Clin Endocrinol Metab 2001, 86: I | 44-I I 48.

110. Benoit SC, Clegg DJ, Barrera JG, Seeley RJ, Woods SC: Learned meal initiation attenuates the anorexic effects of the melanocortin agonist MTII. Diabetes 2003, 52:2684-2688.

III. Trevaskis JL, Butler AA: Double leptin and melanocortin-4 receptor gene mutations have an additive effect on fat mass and are associated with reduced effects of leptin on weight loss and food intake. Endocrinology 2005, 146:4257-4265.

1 12. Butler AA, Kesterson RA, Khong K, Cullen MJ, Pelleymounter MA, Dekoning J, Baetscher M, Cone RD: A unique metabolic syndrome causes obesity in the melanocortin-3 receptor-deficient mouse. Endocrinology 2000, 141:3518-3521.

113. Chen AS, Marsh DJ, Trumbauer ME, Frazier EG, Guan X-M, Yu H, Rosenblum Cl, Vongs A, Feng Y, Cao L, Metzger JM, Strack AM, Camacho RE, Mellin TN, Nunes CN, Min W, Fisher J, Gopal-Truter S, Maclntyre DE, Chen HY, Van der Ploeg LHT: Inactivation of the mouse melanocortin- 3 receptor results in increased fat mass and reduced lean body mass. Nat Genet 2000, 26:97-102.

114. Sutton GM, Trevaskis JL, Hulver MW, McMillan RP, Markward NJ, Babin MJ, Meyer EA, Butler AA: Diet-genotype interactions in the development of the obese, insulin-resistant phenotype of C57BL/6J mice lacking melanocortin-3 or -4 receptors. Endocrinology 2006, I 47:2183-2196.

II5. Schalin-Jäntti C, Valli-Jaakola K, Oksanen L, Martelin E, Laitinen K, Krusius T, Mustajoki P, Heikinheimo M, Kontula K: Melanocortin3-receptor gene variants in morbid obesity. Int J Obes 2003, 27:70-74.
116. Zhang Y, Kilroy GE, Henegan TM, Prpic-Uhing V, Richards WG, Bannon AW, Mynatt RL, Gettys TW: Targeted deletion of melanocortin receptor subtypes 3 and 4 , but not CART, alters nutrient portioning and compromises behavioral and metabolic responses to leptin. FASEB J 2005, I 9: | 482-I49|.

117. Roselli-Rehfuss L, Mountjoy KG, Robbins LS, Mortrud MT, Low MJ, Tatro JB, Entwistle ML, Simerly RB, Cone RD: Identification of a receptor for $\gamma$ melanotropin and other proopiomelanocortin peptides in the hypothalamus and limbic system. Proc Natl Acad Sci USA 1993, 90:8856-8860.

I I8. Jégou S, Boutelet I, Vaudry H: Melanocortin-3 receptor mRNA expression in pro-opiomelanocortin neurones of the rat arcuate nucleus. J Neuroendocrinol 2000, I 2:50 I-505.

119. Chen YY, Pelletier G: Demonstration of contacts between proopiomelanocortin neurons in the rat hypothalamus. Neurosci Lett 1983, 43:271-276.

120. Tung YCL, Piper SJ, Yeung D, O'Rahilly S, Coll AP: A comparative study of the central effects of specific proopiomelanocortin (POMC)-derived melanocortin peptides on food intake and body weight in Pomc null mice. Endocrinology 2007, 147:5940-5947.

121. Tsigos C, Crosby SR, Gibson S, Young RJ, White A: Proopiomelanocortin is the predominant adrenocorticotropinrelated peptide in human cerebrospinal fluid. J Clin Endocrinol Metab 1993, 76:620-624.

122. Pritchard LE, Oliver RL, McLoughlin JD, Birtles S, Lawrence CB, Turnbull $A V$, White $A$ : Proopiomelanocortin-derived peptides in rat cerebrospinal fluid and hypothalamic extracts: evidence that secretion is regulated with respect to energy balance. Endocrinology 2003, 144:760-766.

123. Abbott CR, Rossi M, Kim M-S, Al Ahmed SH, Taylor GM, Ghatei MA, Smith DM, Bloom SR: Investigation of the melanocyte stimulating hormones on food intake. Lack of evidence to support a role for the melanocortin-3-receptor. Brain Res 2000, 869:203-210.

124. Kask A, Rägo L, Wikberg JES, Schiöth HB: Differential effects of melanocortin peptides on ingestive behaviour in rats: evidence against the involvement of $\mathrm{MC}_{3}$ receptor in the regulation of food intake. Neurosci Lett 2000, 283: I-4.

125. Loh Y, Eskay RL, Brownstein M: MSH-like peptides in rat brain: identification and changes in level during development. Biochem Biophys Res Commun 1980, 94:916-923.

126. Guo L, Munzberg H, Stuart RC, Nillni EA, Bjorbaek C: N-acetylation of hypothalamic alpha-melanocyte-stimulating hormone and regulation by leptin. Proc Natl Acad Sci USA 2004, I0I:II797-II802.

127. Schiöth HB, Muceniece R, Larsson M, Mutulis F, Szardenings M, Prusis $P$, Lindeberg G, Wikberg JES: Binding of cyclic and linear MSH core peptides to the melanocortin receptor subtypes. Eur J Pharmacol 1997, 3 19:369-373.

128. Hsiung HM, Hertel J, Zhang XY, Smith DP, Smiley DL, Heiman ML, Yang DD, Husain S, Mayer JP, Zhang L, Mo H, Yan LZ: A novel and selective beta-melanocyte-stimulating hormone-derived peptide agonist for melanocortin 4. receptor potently decreased food intake and body weight gain in diet-induced obese rats. Endocrinology 2005, I 46:5257-5266.

129. Biebermann $H$, Castaneda TR, van Landeghem $F$, von Deimling $A$, Escher F, Brabant G, Hebebrand J, Hinney A, Tschop MH, Gruters A, Krude $\mathrm{H}$ : A role for beta-melanocyte-stimulating hormone in human body-weight regulation. Cell Metab 2006, 3: I4I-I 46.

130. Grandison L, Guidotti A: Stimulation of food intake by muscimol and beta endorphin. Neuropharmacology 1977, 16:533-536.

131. Jackson HC, Sewell RDE: Are $\delta$-opioid receptors involved in the regulation of food and water intake? Neuropharmacology 1985 , 24:885-888

132. Morley JE, Levine AS: Dynorphin $(1-\mid 3)$ induces spontaneous feeding in rats. Life Sci 1983, 29: 190I-1903.

133. Kieffer BL: Opioids: first lessons from knockout mice. Trends Pharmacol Sci 1999, 20:19-26.

134. Lambert PD, Wilding JPH, Al-Dokhayel AAM, Gilbey SG, Bloom SR: The effect of central blockade of kappa-opioid receptors on neuropeptide Y-induced feeding in the rat. Brain Res 1993, 629: $146-148$.

135. Rubinstein M, Mogil JS, Japón M, Chan EC, Allen RG, Low MJ: Absence of opioid stress-induced analgesia in mice lacking $\beta$ - 
endorphin by site-directed mutagenesis. Proc Natl Acad Sci USA 1996, 93:3995-4000.

136. Appleyard SM, Hayward M, Young JI, Butler AA, Cone RD, Rubinstein $M$, Low MJ: A role for the endogenous opioid beta-endorphin in energy homeostasis. Endocrinology 2003, I44:1753-1760.

137. Zhang R, Hisano S, Chikamori-Aoyama M, Daikoku S: Synaptic association between enkephalin-containing axon terminals and proopiomelanocortin-containing neurons in the arcuate nucleus of rat hypothalamus. Neurosci Lett 1987, 82: I5I-I56.

138. Will MJ, Franzblau EB, Kelley AE: Nucleus accumbens $\mu$-opioids regulate intake of a high-fat diet via activation of a distributed brain network. J Neurosci 2003, 23:2882-2888.

139. Balthasar N, Dalgaard LT, Lee CE, Yu J, Funahashi H, Williams T, Ferreira M, Tang V, McGovern RA, Kenny CD, Christiansen LM, Edelstein E, Choi B, Boss O, Aschkenasi C, Zhang CY, Mountjoy K, Kishi $\mathrm{T}$, Elmquist JK, Lowell BB: Divergence of melanocortin pathways in the control of food intake and energy expenditure. Cell 2005, I 23:493-505.

140. McMinn JE, Wilkinson CW, Havel PJ, Woods SC, Schwartz MW: Effect of intracerebroventricular $\alpha-\mathrm{MSH}$ on food intake, adiposity, c-Fos induction, and neuropeptide expression. Am J Physiol 2000, 279(2):R695-R703.

14I. Davidowa H, Li Y, Plagemann A: Altered responses to orexigenic (AGRP, MCH) and anorexigenic ( $\alpha$-MSH, CART) neuropeptides of paraventricular hypothalamic neurons in early postnatally overfed rats. Eur J Neurosci 2003, | 8:6 |3-62I.

142. Kim EM, Grace MK, O'Hare E, Billington C], Levine AS: Injection of alpha-MSH, but not beta-endorphin, into the PVN decreases POMC gene expression in the ARC. Neuroreport 2002, 1 3:497-500.

143. Barnikol-Watanabe S, Gross NA, Gotz H, Henkel T, Karabinos A, Kratzin H, Barnikol HU, Hilschmann N: Human protein NEFA, a novel DNA binding/EF-hand/leucine zipper protein: molecular cloning and sequence analysis of the CDNA, isolation and characterization of the protein. Biol Chem Hoppe-Seyler 1994, 375:497-5I2.

144. Caldwell GM, Eddy RL, Day CD, Haley LH, Cooper PR, Sait SSJ, Hejtmancik F, Smith RJH, Morton CC, Higgins MJ, Shows TB: Mapping of genes and transcribed sequences in a gene rich $400-\mathrm{kb}$ region on human chromosome I I p I 5. I-p I 4. Cytogenet Cell Genet 200I, 92:103-107.

145. Oh-I S, Shimizu H, Satoh J, Okada S, Adachi S, Inoue K, Eguchi H, Yamamoto M, Imaki T, Hashimoto K, Tsuchiya $T$, Monden $T$, Horiguchi K, Yamada M, Mori M: Identification of nesfatin-I as a satiety molecule in the hypothalamus. Nature 2006, 443:709-7I2.

146. Fekete C, Légrádi G, Mihály E, Tatro JB, Rand WM, Lechan RM: $\alpha$ melanocyte stimulating hormone prevents fasting-induced suppression of corticotropin-releasing hormone gene expression in the rat hypothalamic paraventricular nucleus. Neurosci Lett 2000, 289:।52-I56.

147. Lu X-Y, Barsh GS, Akil H, Watson SJ: Interaction between $\alpha$ melanocyte-stimulating hormone and corticotropin-releasing hormone in the regulation of feeding and hypothalamopituitary-adrenal responses. J Neurosci 2003, 23:7863-7872.

148. Kim MS, Small CJ, Russell SH, Morgan DGA, Abbott CR, AlAhmed SH, Hay DL, Ghatei MA, Smith DM, Bloom SR: Effects of melanocortin receptor ligands on thyrotropin-releasing hormone release: evidence for the differential roles of melanocortin 3 and 4 receptors. J Neuroendocrinol 2002, 14:276-282.

149. Martin NM, Small C], Sajedi A, Liao XH, Weiss RE, Gardiner JV, Ghatei MA, Bloom SR: Abnormalities of the hypothalamo-pituitary-thyroid axis in the pro-opiomelanocortin deficient mouse. Regul Pept 2004, I 22:169-172.

150. Anand BK, Brobeck JR: Localization of a "feeding centre" in the hypothalamus of the rat. Proc Soc Exp Biol Med 1951, 77:323-324.

15I. Bouret SG, Draper S], Simerly RB: Trophic action of leptin on hypothalamic neurons that regulate feeding. Science 2004 , 304: 108-II0.

152. Elias CF, Saper CB, Maratos-Flier E, Tritos NA, Lee C, Kelly J, Tatro JB, Hoffman GE, Ollmann MM, Barsh GS, Sakurai T, Yanagisawa M, Elmquist JK: Chemically defined projections linking the mediobasal hypothalamus and the lateral hypothalamic area. J Comp Neurol 1998, 402:442-459.

153. Abbott CR, Kennedy AR, Wren AM, Rossi M, Murphy KG, Seal LJ, Todd JF, Ghatei MA, Small CJ, Bloom SR: Identification of hypoth- alamic nuclei involved in the orexigenic effect of melaninconcentrating hormone. Endocrinology 2003, I 44:3943-3949.

154. Rossi M, Choi SJ, O'Shea D, Miyoshi T, Ghatei MA, Bloom SR: Melanin-concentrating hormone acutely stimulates feeding, but chronic administration has no effect on body weight. Endocrinology 1997, 138:35I-355.

155. Dube MG, Kalra SP, Kalra PS: Food intake elicited by central administration of orexins/hypocretins: identification of hypothalamic sites of action. Brain Res 1999, 842:473-477.

156. Horvath TL, Diano S, van den Pol AN: Synaptic interaction between hypocretin (orexin) and neuropeptide $Y$ cells in the rodent and primate hypothalamus: a novel circuit implicated in metabolic and endocrine regulations. J Neurosci 1999, 19:1072-1087.

157. Muroya S, Funahashi H, Yamanaka A, Kohno D, Uramura K, Nambu T, Shibahara M, Kuramochi M, Takigawa M, Yanagisawa M, Sakurai T, Shioda S, Yada T: Orexins (hypocretins) directly interact with neuropeptide $Y$, POMC and glucose-responsive neurons to regulate $\mathrm{Ca}^{2+}$ signaling in a reciprocal manner to leptin: orexigenic neuronal pathways in the mediobasal hypothalamus. Eur J Neurosci 2004, 19:1524-1534.

158. Ma X, Zubcevic L, Bruning JC, Ashcroft FM, Burdakov D: Electrical inhibition of identified anorexigenic POMC neurons by orexin/hypocretin. J Neurosci 2007, 27:1529-1533.

159. Aravich PF, Sclafani A: Paraventricular hypothalamic lesions and medial hypothalamic knife cuts produce similar hyperphagia syndromes. Behav Neurosci 1983, 97:970-983.

160. Singru PS, Fekete C, Lechan RM: Neuroanatomical evidence for participation of the hypothalamic dorsomedial nucleus (DMN) in regulation of the hypothalamic paraventricular nucleus (PVN) by alpha-melanocyte stimulating hormone. Brain Res 2005, 1064:42-5I.

161. Kesterson RA, Huszar D, Lynch CA, Simerly RB, Cone RD: Induction of neuropeptide $Y$ gene expression in the dorsal medial hypothalamic nucleus in two models of the agouti obesity syndrome. Mol Endocrinol 1997, I I:630-637.

162. Bernardis LL, Bellinger LL: The dorsomedial hypothalamic nucleus revisited: 1998 update. Proc Soc Exp Biol Med 1998, 21 8:284-306

163. Weindl A, Sofroniew MV: The morphology of LRH and oxytocin neurons. Exp Brain Res 198I, Suppl 3:1-17.

164. Park ES, Jo S, Yi SJ, Kim JS, Lee HS, Lee IS, Seo KM, Sung JK, Lee I, Yoon YS: Effect of capsaicin on cholecystokinin and neuropeptide $Y$ expression in the brain of high-fat diet fed rats. J Vet Med Sci 2004, 66:107-1/14.

165. Butler AA, Marks DL, Fan W, Kuhn CM, Bartolome M, Cone RD: Melanocortin-4 receptor is required for acute homeostatic responses to increased dietary fat. Nat Neurosci 200I, 4:605-6II.

166. Satoh N, Ogawa Y, Katsuura G, Tsuji T, Masuzaki H, Hiraoka J, Okazaki T, Tamaki M, Hayase M, Yoshimasa Y, Nishi S, Hosoda K, Nakao $\mathrm{K}$ : Pathophysiological significance of the obese gene product, leptin, in ventromedial hypothalamus (VMH)-lesioned rats: evidence for loss of its satiety effect in $\mathrm{VMH}$-lesioned rats. Endocrinology 1997, 138:947-954.

167. Li YZ, Davidowa H: Food deprivation decreases responsiveness of ventromedial hypothalamic neurons to melanocortins. I Neurosci Res 2004, 77:596-602.

168. Yeo GS, Connie Hung CC, Rochford J, Keogh J, Gray J, Sivaramakrishnan S, O'Rahilly S, Farooqi IS: A de novo mutation affecting human TrkB associated with severe obesity and developmental delay. Nat Neurosci 2004, 7: I 87-I I 89.

169. Duan W, Guo Z, Jiang H, Ware M, Mattson MP: Reversal of behavioral and metabolic abnormalities, and insulin resistance syndrome, by dietary restriction in mice deficient in brainderived neurotrophic factor. Endocrinology 2003, 144:2446-2453.

170. Xu B, Goulding EH, Zang K, Cepoi D, Cone RD, Jones KR, Tecott LH, Reichardt LF: Brain-derived neurotrophic factor regulates energy balance downstream of melanocortin-4 receptor. Nat Neurosci 2003, 6:736-742.

17I. Zhou X, De Schepper J, Vergeylen A, Luis O, Delhase M, HooghePeters EL: Cafeteria diet-induced obese rats have an increased somatostatin protein content and gene expression in the periventricular nucleus. J Endocrinol Invest 1997, 20:264-269. 
172. Fodor M, Csaba Z, Epelbaum J, Vaudry H, Jegou S: Interrelations between hypothalamic somatostatin and proopiomelanocortin neurons. J Neuroendocrinol 1998, 10:75-78.

173. Bassareo V, Di Chiara G: Differential influence of associative and non-associative learning mechanisms on the responsiveness of prefrontal and accumbal dopamine transmission to food stimuli in rats fed ad libitum. J Neurosci 1997, 17:85I-86I.

174. Molyneux A: Nicotine replacement therapy. Br Med J 2004, 328:454-456.

175. Svenningsson P, Johansson B, Fredholm BB: Caffeine-induced expression of c-fos mRNA and NGFI-A mRNA in caudate putamen and in nucleus accumbens are differentially affected by the $\mathrm{N}$-methyl-D-aspartate receptor antagonist MK-80 I. Mol Brain Res 1996, 35:183-189.

176. Zheng H, Corkern M, Stoyanova I, Patterson LM, Tian R, Berthoud HR: Peptides that regulate food intake: appetite-inducing accumbens manipulation activates hypothalamic orexin neurons and inhibits POMC neurons. Am J Physiol 2003, 284: RI436-R I444.

177. Davis M, Rainnie D, Cassell M: Neurotransmission in the rat amygdala related to fear and anxiety. Trends Neurosci 1994, 17:208-2|4.

178. Pitkänen A, Savander V, Le Doux JE: Organization of intra-amygdaloid circuitries in the rat: an emerging framework for understanding functions of the amygdala. Trends Neurosci 1997 , 20:517-523.

179. Merali Z, Mclntosh J, Kent P, Michaud D, Anisman H: Aversive and appetitive events evoke the release of corticotropin-releasing hormone and bombesin-like peptides at the central nucleus of the amygdala. J Neurosci 1998, 18:4758-4766.

180. Gu D, O'Dell SD, Chen X, Miller G], Day INM: Evidence of multiple causal sites affecting weight in the IGF2-INS-TH region of human chromosome II. Hum Genet 2002, I 1 0:173-I8I.

181. Pearcey SM, De Castro JM: Food intake and meal patterns of weight-stable and weight-gaining persons. Am J Clin Nutr 2002, 76:107-II2.

182. Pérusse L, Bouchard C: Genotype-environment interaction in human obesity. Nutr Rev 1999, 57:S3I-S38.

183. Tackling Obesity in England: The Stationery Office, London; 2001.

184. Farooqi IS, O'Rahilly S: Monogenic human obesity syndromes. Recent Prog Horm Res 2004, 59:409-424.

185. Michaud JL, Rosenquist T, May NR, Fan C-M: Development of neuroendocrine lineages requires the bHLH-PAS transcription factor SIMI. Genes Dev 1998, I2:3264-3275.

186. Kublaoui BM, Holder JL Jr, Gemelli T, Zinn AR: Sim I haploinsufficiency impairs melanocortin-mediated anorexia and activation of paraventricular nucleus neurons. Mol Endocrinol 2006 20:2483-2492.

187. Santoro N, Perrone L, Cirillo G, Raimondo P, Amato A, Coppola F, Santarpia M, D'Aniello A, Miraglia Del Giudice E: Weight loss in obese children carrying the proopiomelanocortin R236C variant. J Endocrinol Invest 2006, 29:226-230.
Publish with Bio Med Central and every scientist can read your work free of charge

"BioMed Central will be the most significant development for disseminating the results of biomedical research in our lifetime. "

Sir Paul Nurse, Cancer Research UK

Your research papers will be:

- available free of charge to the entire biomedical community

- peer reviewed and published immediately upon acceptance

- cited in PubMed and archived on PubMed Central

- yours - you keep the copyright
BioMedcentral 